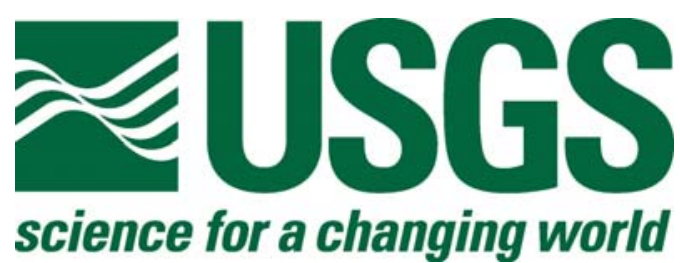

\title{
Brookian structural plays in the National Petroleum Reserve, Alaska
}

by Christopher J. Potter ${ }^{1}$ and Thomas E. Moore ${ }^{2}$

Open-File Report 03-266

2003

This report is preliminary and has not been reviewed for conformity with U.S. Geological Survey editorial standards or with the North American Stratigraphic Code. Any use of trade, firm, or product names is for descriptive purposes only and does not imply endorsement by the U.S. Government.

U.S. DEPARTMENT OF THE INTERIOR

U.S. GEOLOGICAL SURVEY

${ }^{1}$ U.S. Geological Survey, Denver, Colorado 80225

${ }^{2}$ U.S. Geological Survey, Menlo Park, California 94025 


\title{
TABLE OF CONTENTS
}

\author{
ABSTRACT \\ OVERVIEW OF THE BROOKIAN STRUCTURAL PLAYS \\ THERMAL CONSIDERATIONS \\ STRUCTURAL CLOSURE ANALYSIS \\ BROOKIAN TOPSET STRUCTURAL PLAY \\ PLAY ATTRIBUTES \\ Volumetric Parameters \\ Reservoir thickness \\ Area of closure \\ Porosity and hydrocarbon pore volume \\ Trap Fill \\ Trap depth \\ Number of prospects \\ Oil and Gas parameters \\ Oil recovery factor \\ Non-associated gas recovery factor \\ Oil gravity and sulfur content \\ GOR at median depth \\ Probability of occurrence \\ Play \\ Prospect \\ Charge \\ Trap \\ Timing \\ Aggregate Risking Parameters \\ Fraction of accumulations being oil \\ RESULTS \\ TOROK STRUCTURAL PLAY \\ PLAY ATTRIBUTES \\ Volumetric Parameters \\ Reservoir thickness \\ Area of closure \\ Porosity and hydrocarbon pore volume \\ Trap Fill \\ Trap depth \\ Number of prospects
}




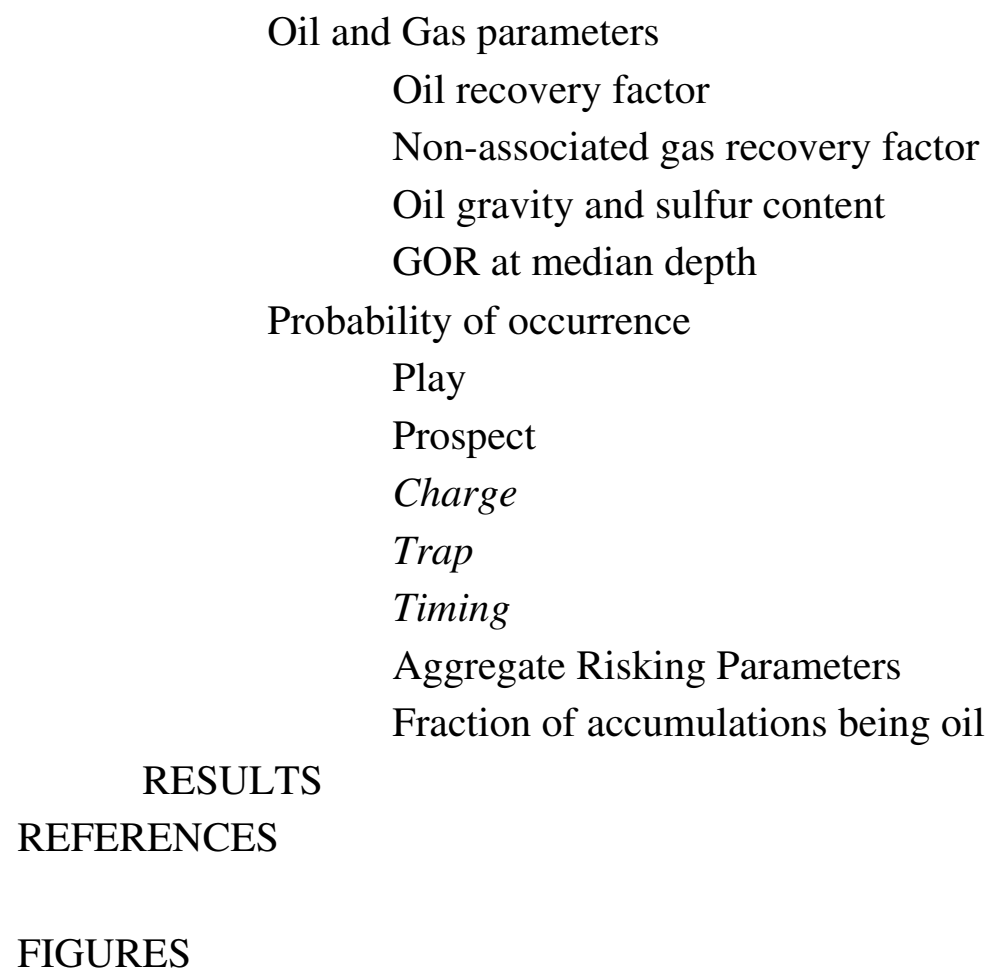

TS1. Brookian Topset Structural Play superimposed on LANDSAT false-color satellite image.

TS2. Torok Structural Play superimposed on LANDSAT false-color satellite image.

TS3. Generalized regional cross section showing structural setting of the Brookian Topset and Torok Structural Plays, along with Ellesmerian Structural Play and Thrust Belt Play, which are discussed in Chapter ES (this volume). Brookian structural domains 1 and 2 are described in text. A indicates the apex (northern tip) of Torok passive-roof duplex (domain 2) at depth. Cross-hatched pattern indicates approximate position of oil window. Top of oil window defined by $\mathrm{R}_{\mathrm{o}}=0.6$; base of oil window defined by $\mathrm{R}_{\mathrm{o}}=1.3$.

TS4. Seismic reflection data from NPRA Regional line R-10 illustrating Umiat Anticline and broad, low-amplitude anticline to its north.

TS5. Seismic reflection data from south end of NPRA Regional line R-7, near West Kurupa 1, illustrating interpretation of the tip of a passive roof duplex, within which thrust-faulted anticlines are developed in lower Torok Formation sandstones beneath the composite Kurupa anticline and adjacent syncline. The point labeled $\mathrm{A}$ is interpreted as the apex of Torok tectonic wedge (passive roof 
duplex), and corresponds to point labeled $\mathbf{A}$ in the generalized cross section shown in figure TS3.

TS6. Saltus and others (this volume, Chapter SM) analyses of structural closures using Tetra Tech (1982) Horizon 500, with key anticlines labeled. Horizon 500 is within the Brookian topset seismic facies. Scale is nonlinear. Elevations above ground elevation represent projection of eroded horizon above ground surface. Processing artifacts are related to correction of datum shifts (Saltus and others, this volume, Chapter SM), and do not reflect geologic structure. Closure labeled $\mathrm{M}$ corresponds to the median area of closure specified for this play.

TS7. Hydrocarbon shows in Nanushuk Group, in exploration wells in and near NPRA. Brookian Topset Structural Play area is shaded blue.

TS8. Summary of oil accumulation sizes estimated for Brookian Topset Structural Play based on mean estimates of technically recoverable resources. A.) Estimated number of oil accumulations by size class. B.) Estimated volume of oil in accumulations of various size class.

TS9. Summary of natural gas accumulation sizes estimated for Brookian Topset Structural Play based on mean estimates of technically recoverable resources. A.) Estimated number of gas accumulations by size class. B.) Estimated volume of gas in accumulations of various size class.

TS10. Seismic reflection data from NPRA Regional line R-19 showing folds in lower Torok Formation.

TS11. Hydrocarbon shows in Torok Formation, in exploration wells in and near NPRA. Northern boundary of Torok Structural Play corresponds to deformation front.

TS12. Summary of oil accumulation sizes estimated for Torok Structural Play based on mean estimates of technically recoverable resources. A.) Estimated number of oil accumulations by size class. B.) Estimated volume of oil in accumulations of various size class.

TS13. Summary of natural gas accumulation sizes estimated for the Torok Structural Play based on mean estimates of technically recoverable resources. A.) Estimated number of gas accumulations by size class. B.) Estimated volume of gas in accumulations of various size class. 


\section{TABLES}

Table TS1. Probability distribution of volumetric and spatial parameters for oil and gas in Brookian Topset Structural Play. LTP, left truncation point defining the lowest values for each parameter considered in the statistical distribution (Scheunemeyer, Chapter ME, this volume).

Table TS2. Oil and gas parameters for Brookian Topset Structural Play.

Table TS3. Probability of occurrence for play and prospects, Brookian Topset Structural Play

Table TS4. Estimates of volumes of technically recoverable hydrocarbons in the Brookian Topset Structural Play in NPRA.

Table TS5. Probability distribution of volumetric and spatial parameters for oil and gas in Torok Structural Play. LTP, left truncation point defining the lowest values for each parameter considered in the statistical distribution (Scheunemeyer, Chapter ME, this volume).

Table TS6. Oil and gas parameters for Torok Structural Play.

Table TS7. Probability of occurrence for play and prospects, Torok Structural Play

Table TS8. Estimates of volumes of technically recoverable hydrocarbons in the Torok Structural Play in NPRA. 


\begin{abstract}
As part of the U.S. Geological Survey assessment of undiscovered oil and gas resources in the National Petroleum Reserve-Alaska (NPRA), two structural plays were assessed in thrust-faulted and folded Upper Cretaceous rocks of the Brookian megasequence. These are the Brookian Topset Structural Play and the Torok Structural Play, located in the Brooks Range foothills and the southern part of the coastal plain, within the Tertiary-age frontal part of the Jurassic to Tertiary Brooks Range orogenic belt. A new regional structural interpretation, developed through regional seismic analyses, reconnaissance field investigations, and new thermal constraints, guided the geologic evaluation and risking of these plays. Volumetric parameters were derived from seismic reflection data, well data and oil and gas field analogs.

The fundamental elements of the Brookian Topset Structural Play, exemplified by the undeveloped Umiat oil field, include: (1) reservoirs in Nanushuk Group and uppermost Torok Formation shallow-marine to nonmarine sandstones draped over anticlines caused by structural thickening in underlying Torok mudstones; (2) seals provided by overlying shale drapes in the Nanushuk, and locally by thrust faults; (3) Torok, gamma-ray-zone (GRZ) or pebble shale source rocks; (4) remigration of hydrocarbons from early formed (Late Cretaceous) stratigraphic traps disrupted by $60 \mathrm{Ma}$ thrusting, into newly formed structural traps. The $60 \mathrm{Ma}$ thrusting was probably accompanied by new generation and migration of natural gas resulting from late structural thickening and tectonic loading. Subsurface data from the Umiat field and other seismic reflection data within the play area indicate that the structural traps are commonly compartmentalized by thrust faults.

The fundamental elements of the Torok Structural Play, exemplified by the undeveloped East Kurupa gas accumulation just south of NPRA, include: (1) reservoirs in lower Torok Formation basin-floor sandstones, and perhaps in small sandstone bodies intercalated with middle to upper Torok mudstones; (2) structural traps provided by folded sandstone bodies above thrust faults within a pervasively deformed passive-roof duplex beneath the foothills and a less-strongly deformed domain to the north; (3) seals provided by Torok mudstone, both stratigraphically above the sandstone bodies and smeared along bounding thrust faults; (4) Torok, GRZ, pebble shale, or Kingak Shale source rocks; (5) a migration and charging scenario similar to that of the Brookian Topset Structural Play.
\end{abstract}


According to our estimates, the Brookian Topset Structural Play contains 137 million barrels of technically recoverable oil and 10.6 trillion cubic feet (TCF) of technically recoverable, non-associated natural gas, with both values representing the mean estimate (expected value). The Torok Structural Play contains about 35 million barrels of technically recoverable oil and 17.9 TCF of technically recoverable, nonassociated natural gas. 


\section{OVERVIEW OF THE BROOKIAN STRUCTURAL PLAYS}

The two Brookian structural plays (figs. TS1, TS2) are defined by structural traps produced by Tertiary folds and thrust faults in the Brookian megasequence (Bird, this volume, Chapter GS) in the foothills and southern part of the coastal plain of NPRA. These structures compose the frontal part of the Jurassic to Tertiary Brooks Range orogenic belt. The Brookian Topset Structural Play is developed within the topset seismic-stratigraphic facies (Houseknecht, this volume, Chapter BK) in shallow-marine to nonmarine Albian strata of the Nanushuk Group and uppermost Torok Formation. The Torok Structural Play is developed within deep-water basin-floor sandstones (coalesced lowstand-systems tract deposits, Houseknecht and Schenk, 2001) within the lower Torok. In both of these plays, reservoir facies are deformed to varying degrees in anticlinal folds that are genetically related to late Tertiary thrust faulting.

Figures TS1 and TS2 show the play boundaries for the Brookian Topset and Torok Structural Plays. The Tertiary deformation front defines the northern boundary for both of these plays. The southern boundary of the Brookian Topset Structural Play is defined by the Tuktu Escarpment (fig. TS1), which is the southern limit of exposures of the Nanushuk and upper Torok topset facies. The southern boundary of the Torok Structural Play is defined by the southern limit of exposures of Torok (some of which have been mapped as Cretaceous Fortress Mountain Formation; for example, Mayfield and others, 1988) in the foothills of southern NPRA.

Figure TS3 shows the overall structural setting of these two plays and the other two structural plays in the NPRA assessment (discussed in Chapter ES). This figure illustrates the southward-increasing complexity of deformation of Brookian strata in southern NPRA, and the complexly deformed older strata to the south and at depth (Moore and Potter, Chapter ES, this volume,). Figure TS3 illustrates two principal structural domains within the deformed Brookian rocks. Beneath the central and southern parts of the coastal plain, the topset reflectors have been folded. The folds were apparently caused by local structural thickening and thinning in the mudstone-rich Torok Formation that underlies the more sandstone-rich topset facies. This is a domain of incipient deformation (domain 1), controlled by local detachments within the Brookian section rather than by throughgoing regional detachments. To the south, a complex passive-roof duplex (domain 2) is developed principally within the Torok in the foothills, south of the coastal plain. The boundary between domains 1 and 2, defined by the roof thrust of this passive-roof duplex, intersects the ground surface considerably south of the 
Tuktu Escarpment and dips north in the subsurface, continuing at depth to point A (fig. TS3) more than 10 mi north of the Tuktu Escarpment.

The Tertiary deformation front (figs. TS1,TS2, TS3) corresponds to the northern extent of a broad, low-amplitude welt of structurally thickened Torok Formation that is characterized by a chaotic internal reflection pattern beneath the well-defined reflections of the broadly warped Nanushuk and upper Torok topset reflectors (fig. TS4). The deformation front crosses northern and east-central NPRA just south of the Tunalik 1, Kugrua 1, South Meade 1, Inigok 1 wells, and passes just south of the Tulaga 1 well east of NPRA. Regionally, the frontal welt, which underlies the northern part of domain 1 , actually comprises several broad, low-amplitude anticlines that overlap in map view.

The southern part of domain 1, beneath the southern part of the coastal plain, is characterized by well-defined higher-amplitude "Umiat-type" anticlines, named for the Umiat oil field in southeastern NPRA (fig. TS4). Like the broad welt to the north, these anticlines are developed above structurally thickened Torok Formation. In addition, Umiat-style anticlines overlie thrust splays and ramps that pass upward from the Jurassic and Cretaceous Kingak Shale into the Torok. Most of the Umiat-style anticlines, such as the Big Bend and Grandstand Anticlines south of the southeastern corner of NPRA, and the Awuna and Knifeblade Anticlines within NPRA, are not underlain by a regional detachment within the Brookian section. Rather, these structures were driven by local distributed lateral shortening and vertical thickening in the Torok caused by local transfer of displacement up along splays from the Kingak regional detachment into the Torok. At the position of the northernmost large-amplitude anticlines, such as the Umiat Anticline, the regional detachment ramps up to the base of the upper Torok mudstones and remains at this stratigraphic level beneath the broad low-amplitude welt to the north, right up to the deformation front. Thus, the northern flanks of the northernmost Umiat-style anticlines actually merge with the broad welt to the north (fig. TS4).

Domain 2 is characterized by a regional triangle zone or passive-roof duplex south of the Tuktu Escarpment (figs. TS1, TS3; Moore and Potter, this volume, Chapter ES). The passive-roof duplex formed by imbrication of the lower, sandstone-rich part of the Torok Formation above a floor thrust that is the regional detachment in the Kingak Shale, and beneath a roof thrust in the mudstone-rich middle to upper part of the Torok. Strata of the uppermost Torok and the Nanushuk Group lie above the roof thrust and are only gently folded. In domain 1, north of the triangle zone, seismic data indicate these units are locally concordant on the lower Torok indicating the section is unfaulted. 
Geologic evidence for the passive-roof duplex includes dip reversals and spatial variations in deformational style, documented mainly on a regional traverse in Alaska State lands from Umiat south to the mountain front, but also along regional seismic lines R6, R19, and R22 in and near south-central NPRA (south of the Colville River; figs. TS1, TS2). South of the Tuktu Escarpment, mid-Cretaceous strata are widespread in outcrop and in the subsurface and consist of large thicknesses of mostly south-dipping strata, including sandstone turbidites (Aptian-Albian lower Torok Formation) and overlying mudstone slope deposits (Aptian-Albian upper Torok Formation). To the south, these strata display north-vergent folds and thrust faults, but to the north, become mostly north-dipping with south-vergent folds and thrusts. The boundary or transition between the opposing dip and vergence domains is poorly defined in the field and on seismic data, but is interpreted as the roof thrust separating imbricated, strongly deformed lower Torok (to the south) from a passively deformed roof (to the north). The strongly imbricated Torok beneath the roof thrust forms a north-driven tectonic wedge whose apex lies at depth north of the Tuktu Escarpment. Figure TS5 shows the probable apex of the tectonic wedge north of the Kurupa Anticline near the west Kurupa 1 well (fig. TS2), where the roof thrust of the passive-roof duplex meets the floor thrust.

Involvement of the Aptian-Albian Torok Formation and Nanushuk Group in the thrust-related deformation indicates that these frontal Brookian structures developed after $100 \mathrm{Ma}$. Cole and others (1997) interpreted some seismic reflection patterns to indicate syndepositional (Aptian-Albian) folding of Colville basin deposits, but we consider this evidence to be equivocal. Apatite fission-track analyses indicate a strong pulse of uplift at about $60 \mathrm{Ma}$, and this is generally thought to record the peak age of Tertiary thrusting in the frontal portion of the mountain belt (O'Sullivan and others, 1997). There are no strong stratigraphic constraints on the younger age limit for this deformation.

\section{THERMAL CONSIDERATIONS}

Vitrinite reflectance data indicate that the top of the oil window [vitrinite reflectance $\left(R_{o} 0.6\right)$ ] intersects the ground surface in the lower Nanushuk Group or upper Torok Formation near the Awuna 1 and East and West Kurupa wells [at about lat $69^{\circ} \mathrm{N}$. near the southern edge of the Brookian Topset Structural Play (fig. TS1) and in the southern part of the Torok Structural Play (fig. TS2)]. The top of the oil window dips to the north through the Brookian structural plays (fig. TS3), evidenced by $R_{o} 0.6$ at about $5,600 \mathrm{ft}$ depth in the Torok Formation in the Inigok 1 well just north of the Tertiary deformation front. Through much of the foothills belt south of lat $69^{\circ} \mathrm{N}$., vitrinite reflectance measured in Brookian samples from outcrops and wells indicates that the top 
of the oil window is relatively flat, and near the ground surface, (fig. TS3; K.J. Bird, U.S. Geological Survey, written commun., 2001). The base of the oil window, defined by $R_{o}$ 1.3, lies at 6,000-8,000 $\mathrm{ft}$ (still well within the Brookian megasequence) throughout the northern part of the foothills belt (Awuna, West Kurupa, East Kurupa wells) and descends to the base of the Torok in the northern part of the Brookian structural play areas (fig. TS3). This surface is essentially at the base of the Brookian megasequence in the Oumalik 1 and Seabee 1 wells, at depths of about 11,000 ft and 13,000 ft, respectively, and lies at about 11,000 ft in the Kingak Shale in the Inigok 1 well, just north of the deformation front (fig. TS3). Thus the Nanushuk Group is immature to mature (within the oil window) throughout the Brookian Topset Structural Play. The underlying Torok Formation in the Torok Structural Play is immature to mature in the northern part of the play, and mature to overmature in the southern part of the play area.

Burial history calculations (Burns and others, 2002) suggest that peak generation in the lower Brookian (and subjacent) source rocks occurred at about 100-90 Ma in southern NPRA, indicating that the petroleum systems were active during rapid Brookian deposition in the Colville Basin. The thermal maturity patterns discussed above reflect the effects of uplift and erosion superimposed on the initial geometry of the Colville Basin fill [with possible perturbation of the thermal regime by basin-scale fluid flow (Deming and others, 1992)]. The deepest part of the Colville Basin, with as much as $26,000 \mathrm{ft}(8 \mathrm{~km})$ of Aptian to Cenomanian sedimentary fill, was located in the northern part of the foothills belt, with significant thinning toward the south and north. Hydrocarbons generated during this period of rapid sedimentary burial (well before the $60 \mathrm{Ma}$ deformation event) most likely migrated into nearby stratigraphic traps in Brookian megasequence strata.

\section{STRUCTURAL CLOSURE ANALYSIS}

Saltus and others (this volume, Chapter SM) performed a statistical analysis of four-way structural closures for a number of stratigraphic horizons, using digitized structure-contour maps originally created for NPRA by Tetra Tech $(1980,1982)$. The Tetra Tech maps were based on the complete set of seismic reflection data in NPRA, spaced at $6 \mathrm{mi}$ east-to-west and $8 \mathrm{mi}$ north-to-south rather than just the regional R-lines (Miller and others, 2000, 2001; Kulander and others, this volume), which are spaced at about $20 \mathrm{mi}$ x $20 \mathrm{mi}$, on average. Saltus and others' approach allowed them to map structural closures and to tabulate geometric parameters and sizes for these closures. Using the R-lines, we compared the closure map to actual structures on the seismic lines in order to evaluate data quality of seismic lines used to identify these structures (and thus evaluate the confidence level for interpretations of these closures), and to identify 
geologic factors, such as a high degree of faulting, erosional breaching, or the lack of such complications, that might impact the existence or quality of the structural traps. This qualitative evaluation, along with our direct measurements of structural closures from the regional seismic lines, was used with Saltus and others' statistical results to specify volumetric parameters and frequency-of-occurrence parameters for the structural closures in the Brookian structural plays, as discussed below in the documentations of the specific plays.

\section{BROOKIAN TOPSET STRUCTURAL PLAY}

The fundamental elements of the Brookian Topset Structural Play, as described in the following discussion, include: (1) reservoirs in Nanushuk Group and uppermost Torok Formation shallow-marine to nonmarine sandstones draped over anticlines caused by structural thickening in underlying Torok mudstones; (2) seals provided by overlying shale drapes in the Nanushuk; (3) Torok, gamma-ray-zone (GRZ) or pebble shale source rocks; (4) remigration of hydrocarbons from early formed (Late Cretaceous) stratigraphic traps disrupted by $60 \mathrm{Ma}$ thrusting, into newly formed structural traps. The $60 \mathrm{Ma}$ thrusting was probably accompanied by new generation and migration of natural gas resulting from late structural thickening and tectonic loading.

This play is exemplified by the Umiat oil field, which was discovered in 1946 through drilling near the crest of the Umiat Anticline (figs. TS4, TS6; Molenaar, 1982). Two separate hydrocarbon accumulations were discovered in reservoir sandstones of the late Albian Grandstand Formation in the lower Nanushuk Group, and the Ninuluk Formation in the upper Nanushuk. Locally, there are stacked and isolated oil and gas reservoirs in the Grandstand. These reservoirs are compartmentalized by thrust faults that have propagated upwards from the Torok shales in the core of the anticline into the overlying Nanushuk sandstones that are folded above the structurally thickened Torok. The fact that the oil reservoir lies above the gas reservoir demonstrates that there is no communication between the different fault compartments. The main oil-producing sandstone in the Grandstand is 50-100 ft thick. Two deeper gas-producing sandstones in the Grandstand have similar thicknesses. The average porosity of Grandstand sandstones is about 12 percent, with maximum values of 20 percent. The top of the main oil reservoir is at an elevation of $200 \mathrm{ft}, 450 \mathrm{ft}$ below the land surface, within the permafrost zone. 
Mapping of the oil-water contact in the 12 wells that define the Umiat oil field demonstrates a 7,000-acre area for the field. The vertical closure on the structure is about $650 \mathrm{ft}$ and the overall vertical closure on the trap is about 1,000 ft (Molenaar, 1982). There is a wide range in the estimated oil reserves in the Umiat field caused mainly by a wide range of oil recovery factors used, with most estimates in the range of 30 to 100 million barrels of oil (MMBO), although the widely accepted value for reserves is 70 MMBO (Reed, 1958; Molenaar, 1982).

The oil in the Umiat field has a gravity of 36-37.2 API (Molenaar, 1982), consistent with a Brookian source in the Torok, GRZ or pebble shale.

Several gas accumulations have been discovered in this play through drilling of prominent (Umiat-style) anticlines in the 1940s and 1950s. Although data are insufficient to provide good estimates of total gas volumes, substantial gas accumulations might be present in the Gubik, East Umiat, Meade and Square Lake structures (fig. TS1), with smaller accumulations present in the Wolf Creek and Oumalik structures (Reed, 1958; Kumar and others, 2002). Figure TS7 shows that a mobile gas phase was also present in the Kaolak 1, Knifeblade 2A, and Titaluk 1 wells. The Gubik accumulation was tested by two wells. In the Gubik 1 well, three producing sandstones were tested and at least 10 other sandstones with similar characteristics were untested, whereas in the Gubik 2 well only one sandstone was found to have commercial quantities of gas (Reed, 1958). Several sandy zones produced gas in the Meade 1 well, and two stacked gasproducing sandstone reservoirs are present in the Square Lake 1 well. In East Umiat, drill-stem tests indicate the presence of three principal gas-producing sandstone reservoirs (Kumar and others, 2002).

It is important to note that peak oil generation and migration from lower Brookian source rocks occurred at 100-90 Ma, during a period of rapid Brookian sedimentation and burial (Burns and others, 2002). However, the structural traps in this play did not form until about $60 \mathrm{Ma}$. Thus, early generated oil and gas must have been sequestered in stratigraphic traps in Brookian rocks during the intervening 30-40 m.y. prior to migration into structural traps. Oil and gas accumulations in the Brookian Topset Structural Play may result from the structural disruption of previously formed accumulations, and remigration of fluids into newly formed structural traps (anticlinal traps, locally compartmentalized by faulting). Alternatively, the Umiat oil field could have originated as a 100-Ma stratigraphic trap that was subsequently folded, so that it became a combination structural-stratigraphic trap. Tectonic burial that accompanied structural thickening during the $\sim 60 \mathrm{Ma}$ thrusting would also have resulted in renewed gas 
generation, and this newly generated gas could also have migrated into some of the anticlinal traps.

Comparison of the closure analysis by Saltus and others (this volume, Chapter SM) with our interpretations of the R-lines suggests that Tetra Tech's $(1980,1982)$ seismic interpretation was effective in capturing the geometry of the Umiat-style anticlines, but less so in defining the components of the broad, low-amplitude anticlines just south of the deformation front. These broad anticlines, in which the topset facies is draped over a broad deformed welt of structurally thickened Torok Formation mudstones, form large structural closures that could hypothetically be enormous hydrocarbon traps. However, it is unlikely that high-porosity reservoir rocks are present throughout these structures, so any hydrocarbon accumulations in these structures might be laterally confined by facies transitions. In other words, hydrocarbon accumulations in the sandstone-rich topset-facies strata draped across the welt are likely to exist in combination stratigraphic-structural traps, rather than in very large structural traps.

\section{PLAY ATTRIBUTES}

\section{Volumetric Parameters}

Reservoir thickness The reservoirs within structural traps in the Brookian Topset Structural Play consist of stacked folded sandstone bodies, each of which might be isolated from those above and below it by intervening shale drapes. The net reservoir thickness is interpreted as the total thickness of producing sandstone reservoirs that might be penetrated in a hypothetical oil or gas field. The values specified for reservoir thickness (table TS1) are based on thicknesses interpreted from seismic profiles, and on reservoir thickness data from the Umiat oil field.

The median specified value of 100 feet (125 feet for gas) corresponds to the average net reservoir thickness in the Umiat field, where the main producing reservoir is 50-100 feet thick, with two or three deeper sandstone units of similar thickness locally producing oil (Molenaar, 1982). Although the total thickness of Brookian topset strata involved in these large anticlines ranges up to $6,000 \mathrm{ft}$ and is commonly over 3,000 ft, we specify a maximum net reservoir thickness of $500 \mathrm{ft}$ (600 ft for gas), as we estimate that reservoir-quality sandstones will not exceed 10-20 percent of the total thickness of topset strata, based on well logs in the play area. 
Area of closure. Two separate approaches were taken to quantifying the areas of closures: (1) we measured the widths of anticlinal structures that affect the Brookian topset strata on regional seismic lines, and (2) we used the results of Saltus and others' (this volume, Chapter SM) statistical analysis of four-way closures from the Tetra Tech $(1980,1982)$ interpretations that employed all of the NPRA seismic reflection data.

Using the regional seismic lines, we measured the widths of anticlines crossed by north-south seismic lines. To calculate the areas of Umiat-style anticlines, we assumed an aspect ratio (length/width) of 5.5, corresponding to typical thin-skinned, fold-thrust belt geometry (Perry and others, 1999), and to the geometry of folds mapped in the foothills and southern coastal plain. For the broad, lower-amplitude structures associated with the frontal welt, we used an aspect ratio (length/width) of 2, based on the map pattern of such structures. These assumed aspect ratios allowed calculation of hypothetical areas of elliptical closures. This analysis showed that the areas of closure on Umiat-style anticlines typically range from tens to hundreds of thousands of acres, with a median area of 27,000 acres, whereas closures associated with the frontal welt have a median area of 96,000 acres.

The statistical analysis of Saltus and others (this volume, Chapter SM) that applies to this play is the analysis of closures in the Tetra Tech (1982) Horizon 500, (in Nanushuk Group topset strata). This yields a median value (within the population of closures in excess of the 2,000 acres minimum cutoff value considered) of 15,000 acres, and a maximum value of 104,000 acres.

These very large closure areas apply to sizes of actual anticlines, many of which have been drilled without discovery of any accumulations of this size. In fact, the Umiat field, which has been reasonably well explored and defined by drilling, has an area of 5,000-7,000 acres (Molenaar, 1982), a fraction of the overall size of the Umiat structure. The small area of the Umiat field, (relative to the overall size of the anticline) is related to fault compartmentalization and to its location near the crest of the structure. In our assessment of this play, we considered such fault compartmentalization to be the rule, and accordingly, our median area of closure is chosen at 7,000 acres (table TS1). Allowing for some possibility that a large anticlinal closure might define the size of a hydrocarbon container, we established a maximum value of 75,000 acres, with an F05 (5 percent probability) value of 30,000 acres (table TS1). For very large anticlines in this play, it is unlikely that individual high-porosity reservoir intervals would be draped across the entire structure. This is another factor that might diminish the high end of hypothetical trap sizes. 
Porosity and hydrocarbon pore volume The average porosity in the Umiat oil reservoirs is about 12 percent (Molenaar, 1982), and other porosity measurements in the Umiat field range as high as 20 percent. Average porosity values measured from Nanushuk cores in the Gubik 1, Umiat 11, Knifeblade 2a, Meade, Oumalik, and Square Lake wells lie in the 10-16 percent range, while average values measured from core in the Gubik 2, Kaolak, Knifeblade 1, Titulak, and Wolf Creek wells lie in the 7-10 percent range. In order to capture the range of reservoir-quality sandstones for oil in this play, we specified a lower-truncation-point (LTP) value of 12 percent porosity, with a median of 14 percent and a maximum of 20 percent, for oil (table TS1). For natural gas, the lowertruncation point is set at 10 percent, reflecting the lower porosities allowable in gas reservoirs (table TS1).

We applied a -0.5 correlation between porosity and net reservoir thickness for this play (Scheunemeyer, Chapter ME, this volume). This is because we consider it unlikely that the thickest reservoirs specified under net reservoir thickness will be characterized by the maximum or F05 porosity values. Porosity values of 16-20 percent most likely correspond to original stratigraphic traps that have been preserved or only slightly modified during deformation, and these are likely to be relatively thin reservoirs. Reservoirs that are several hundred feet thick within large anticlinal traps would be expected to be characterized by lower average porosities. Specification of a -0.5 correlation will produce a preferential matching of lower porosity values with high thickness values, while still allowing the possibility of some thick reservoirs with high average porosities.

Unlike the other structural plays in NPRA, we did not apply a correlation between the net reservoir thickness and area of closure for the Brookian Topset Structural Play. This is because all structures we assessed in this play involve the total thickness of Brookian topset strata; therefore, the net reservoir thickness in this play would not be dependent on the area of the structure.

The hydrocarbon pore volume is specified as the difference between the porosity $(\varnothing)$ and the porosity-water saturation product $\left(\varnothing \mathrm{S}_{\mathrm{w}}\right)(\mathrm{Scheunemeyer}$, Chapter $\mathrm{ME}$, this volume). Water saturation is based on analogs from similar lithic arenite reservoirs (Nelson, 1999).

Trap Fill From 10 Cordilleran thrust-belt fields, including the Umiat oil field, Perry and others (1999) determined an average trap fill of about 38 percent and a range from 13 to 100 percent. The Umiat trap is about 65 percent filled with hydrocarbons, based on the height of hydrocarbon column versus height from the top of the trap down to 
the spill point (Molenaar and others, 1982). The trap fill value is dependent on whether one considers a few relatively thin reservoir intervals to make up the volume of the accumulation (in which case the average trap fill would be relatively high), or whether one considers the total vertical closure on the anticline to constitute the trap (in which case the average trap fill would be relatively low). The volumetric attributes in this play allow for both of these kinds of accumulations. In addition, varying degrees of fracturing and faulting can produce widely varying seal integrity. A wide range of trap fill (20-100 percent) is assigned to this play, with a median of 40 percent (table TS1). 
Table TS1. Probability distribution of volumetric and spatial parameters for oil and gas in Brookian Topset Structural Play. LTP, left truncation point defining the lowest values for each parameter considered in the statistical distribution (Scheunemeyer, Chapter ME, this volume).

Attribute

Net Reservoir Thickness (oil)

Net Reservoir Thickness (gas)

Area of Closure (oil)

Area of Closure (gas)

Trap Fill (oil)

Trap Fill (gas)

Porosity (oil)

Porosity (gas)

Porosity-Water Saturation Product

(oil)

Porosity-Water Saturation Product (gas)

Hydrocarbon Pore Volume (oil)

Hydrocarbon Pore Volume (gas)
Units

feet

feet

1000 acres

1000 acres

percent

percent

percent

percent

percent

percent

percent

percent

Trap Depth

Number of Prospects

$1000 \mathrm{ft}$
Probability of attribute greater than

$\begin{array}{rrrr}\text { LTP } & 50 & 5 & \text { Max } \\ 25 & 100 & 400 & 500 \\ 25 & 125 & 450 & 600 \\ 2 & 7 & 30 & 75 \\ 2 & 7 & 30 & 75 \\ 20 & 40 & 80 & 100 \\ 30 & 50 & 80 & 100 \\ 12 & 14 & 17 & 20 \\ 10 & 14 & 17 & 20\end{array}$

6

6

$\begin{array}{llll}6 & 8 & 11 & 14 \\ 4 & 8 & 11 & 14\end{array}$

Min $50 \quad 5 \quad$ Max

$\begin{array}{rrrr}0.5 & 2 & 10 & 12 \\ 60 & 90 & 120 & 150\end{array}$


Trap depth Based on our analysis of seismic reflection data and on the closure analysis of Tetra Tech Horizon 500 (Saltus and others, Chapter SM, this volume, Tetra Tech), we have assigned a median depth of 2,000 ft and a maximum depth of 12,000 ft for accumulations in this play (table TS1). The minimum depth of $500 \mathrm{ft}$ reflects the depth to the base of permafrost.

Number of prospects. The closure analysis for Tetra Tech Horizon 500 (Saltus and others, Chapter SM, this volume) identified 95 structural closures that exceed the minimum area. However, some of these are erosionally breached, and six of the ten structural closures that have been drilled have yielded negative or questionable results (fig. TS6). Therefore, we have established a minimum number of 70 drillable prospects (table TS1). The median and maximum values of 105 and 180 reflect the concept that reservoirs within many of the large anticlines are likely to be compartmentalized, either stratigraphically or structurally, so that there might be more than one prospect in a given anticline.

\section{Oil and Gas parameters}

Oil recovery factor The oil recovery factor in plays that might be significantly affected by faults is set at 35 percent (Verma, Chapter OG, this volume) (table TS2).

Non-associated gas recovery factor The gas recovery factor in plays that might be significantly affected by faults is set at 60 percent (Verma, Chapter OG, this volume) (table TS2).

Oil gravity and sulfur content Oil gravity is assumed to be that of the Umiat oils, 36-37.2 API (Molenaar, 1982), consistent with a Brookian source in the Torok, GRZ, or pebble shale. We have set this value at 37 percent for this play. The sulfur content of Umiat oil is less than 0.1 percent (Brosge and Whittington, 1966); we have set this value at 0.1 percent for this play (table TS2).

GOR at median depth Determination of the gas-oil ratio is discussed by Verma (Chapter OG, this volume). 
Table TS2. Oil and gas parameters for Brookian Topset Structural Play.

\begin{tabular}{llc} 
Parameter & \multicolumn{1}{c}{ Units } & Value \\
Oil recovery factor & percent & 35 \\
Non-associated gas recovery factor & percent & 60 \\
Oil gravity & API degrees & 37 \\
Sulfur content of oil & wt. percent & 0.1 \\
Gas-oil ratio at median depth & cubic ft / bbl & 213
\end{tabular}

\section{Probability of occurrence}

Play This is a proven play because it includes the Umiat oil field, estimated to be well in excess of the $50 \mathrm{MMBO}$, and also includes several gas fields whose volume is less well known. Therefore, at the play level, risking attributes for Charge (C), Trap/Seal (T), and Timing (T) are each set at 1, with an overall play risk (probability that the play contains at least 1 reservoir of at least the minimum size) of 1.0 (table TS3).

Prospect At the prospect level, we have established separate risking parameters for oil and gas, because there are quite distinct scenarios involved with the possibility of oil vs. gas accumulations.

Charge: For an oil charge, our play concept requires the fault-disruption of an early formed Brookian stratigraphic trap, and migration of that oil into a newly-formed structural trap. Because this scenario requires very specific migration paths from pointsource early accumulations, we assigned considerable risk to oil charge, assigning a probability value of 0.2 (table TS3). For a gas charge, we called upon remigrated earlierformed gas as well as gas that was newly generated during thrust loading. Virtually all wells drilled in southern NPRA have encountered gas shows in this play, so gas charge is considered almost ubiquitous. For this reason, we assigned a prospect-level probability of 0.9 for gas charge (table TS3). 
Table TS3. Probability of occurrence for play and prospects, Brookian Topset Structural Play

$\begin{array}{lrr}\text { Play Attributes } & \text { OIL } & \text { GAS } \\ \text { Charge (C) } & 1 & 1 \\ \text { Trap (T) } & 1 & 1 \\ \text { Timing (F) } & 1 & 1 \\ \text { Probability that play contains at least 1 reservoir exceeding } & & 0.9 \\ \text { minimum size (CxTxF) } & 0.2 & 0.2 \\ \text { Prospect Attributes } & 0.3 & 0.9 \\ \text { Charge (c) } & 0.7 & 0.9 \\ \text { Trap (t) } & 0.042 & 0.162 \\ \text { Timing (f) } & & 0.162 \\ \text { Probability that a randomly chosen prospect is favorable (cxtxf) } & 0.042 & \\ & & 0.15\end{array}$

Trap: Although viable reservoir sandstones might be present in numerous prospects in this play, the primary risk in formation of a viable trap lies in the presence of a seal. Many of the stratigraphic seals are expected to be disrupted by faulting, and this will be a greater problem for the more mobile gas phase than for liquid hydrocarbons. For this reason, we set the prospect-level trap (t) probability at 0.3 for oil and 0.2 for gas (table TS3).

Timing: Because the structures in this play are all considered to have formed at about $60 \mathrm{Ma}$, and because it is clear that some structural traps formed at this time were successful in trapping oil and gas, timing of formation of individual structures is likely to be favorable. Because there was probably continuous generation of gas throughout the 
deformational event that formed these structures, we set the prospect-level gas timing risk at 0.9 (table TS3). Because trapping of oil is more dependent on the specific timing of disruption, remigration, and trapping of earlier-formed oil, we set the prospect-level probability for oil timing at 0.7 (table TS3).

Aggregate Risking Parameters Because the play-level risk is 1.0, the aggregate risking parameters are defined by the prospect-level risk (table TS3).

For oil, this risk is $[(\mathrm{CTF}) \times(\mathrm{ctf})]=[1.0 \times(0.2 \times 0.3 \times 0.7)]=0.04$.

For gas, this risk is $[(\mathrm{CTF}) \times(\mathrm{ctf})]=[1.0 \times(0.9 \times 0.2 \times 0.9)]=0.16$.

Fraction of accumulations being oil This value is set at 0.15 for this play, reflecting the overall proportion of oil and gas accumulations (regardless of size) that have been discovered in this play within and near NPRA (table TS3).

\section{RESULTS}

The assessment input values summarized in tables TS1, TS2, and TS3 were used to estimate the petroleum resource potential of the Brookian Topset Structural Play, using the statistical procedures described by Scheunemeyer (Chapter ME, this volume). Results are summarized in table TS4 for technically recoverable crude oil and nonassociated gas. Additional results are provided in Appendix XX.

Table TS4. Estimates of volumes of technically recoverable hydrocarbons in the Brookian Topset Structural Play in NPRA.

\begin{tabular}{|c|c|c|c|c|c|}
\hline & $\underline{\text { Mean }}$ & $\underline{\text { Std. Dev }}$ & $\underline{\mathrm{F}_{9 \underline{5}}}$ & $\underline{\mathrm{F}_{50}}$ & $\underline{\mathrm{F}_{0 \underline{5}}}$ \\
\hline Oil (MMBO) & 137 & 269 & 0 & 0 & 654 \\
\hline Non-associated Gas (BCF) & 10,606 & 4,072 & 4,801 & 10,119 & 18,012 \\
\hline
\end{tabular}


It is estimated that this play contains 137 million barrels of technically recoverable oil and 10.6 trillion cubic feet of technically recoverable, non-associated natural gas, with both values representing the mean estimate (expected value).

The oil and gas resources are estimated to occur in accumulations of various size, as illustrated in figures TS8 and TS9. There is a small probability of the existence of one or more oil accumulations between 16 and 1,024 MMBO in size within the play, and an exceedingly small probability of an accumulation greater than 1,024 MMBO, as illustrated in figure TS8A. Most of the volume of oil within this play is expected to occur in accumulations that fall in the 512 to 1024,256 to 512 , and 128 to $256 \mathrm{MMBO}$ size classes, as shown in figure TS8B.

It is estimated that there is approximately one natural gas accumulation between 1,536 and 3,072 BCF in this play, along with about three in the 768 to 1,536 BCF size class, five in the 384 to 768 BCF size class, and four in the 192 to 384 BCF size class (fig. TS9A). Individual accumulations larger than 3,072 BCF are unlikely (fig. TS9A).

Most of the gas in this play is expected to occur in accumulations that fall between 384 to $1,536 \mathrm{BCF}$, as shown in figure TS9b.

In addition to volumes of crude oil and non-associated gas, this play also contains relatively small volumes of associated natural gas and natural gas liquids, and those values are reported in Appendix XX.

\section{TOROK STRUCTURAL PLAY}

The fundamental elements of the Torok Structural Play, as described in the following discussion, include: (1) reservoirs in lower Torok Formation basin-floor sandstones, and perhaps in small sandstone bodies intercalated with middle to upper Torok mudstones; (2) structural traps provided by folded sandstone bodies above thrust faults within the pervasively deformed passive-roof duplex (structural domain 2) and by fault-bounded sandstone bodies within the structurally thickened Torok in structural domain 1 (fig. TS3); (3) seals provided by Torok mudstone, both stratigraphically above the sandstone bodies and smeared along bounding thrust faults; (4) Torok, GRZ, pebble shale, or Kingak Shale source rocks; (5) probable remigration of hydrocarbons from early formed (Late Cretaceous) stratigraphic traps into newly formed (60 Ma) structural traps, accompanied by new generation and migration of natural gas resulting from late $(\sim 60$ Ma) structural thickening and tectonic loading. 
The main reservoir facies in this play is the lower Torok basin-floor turbidite sandstones. This is the same reservoir unit that is involved in the Brookian Clinoform South-Deep Stratigraphic Play (Houseknecht, chapter BK, this volume). These sandstone bodies are well-imaged on seismic reflection data as a strongly reflective interval beneath the less reflective, commonly structurally disrupted, upper Torok. [The lower Torok is commonly referred to as the "Fortress Mountain Formation" in well logs and oil-industry reports (for example, Tetra Tech, 1980). However, the term Fortress Mountain Formation is reserved for coarse clastic Aptian-Albian fan-delta deposits shed northward from the mountain front along the southern margin of the Colville basin.] There might be additional reservoir sandstones intercalated with the middle and upper Torok mudstones but their distribution and reservoir quality are poorly known. The lower Torok sandstones have been penetrated by drilling beneath several anticlines, including the Umiat (Seabee 1), Kurupa (East Kurupa 1, West Kurupa 1), Big Bend, and Awuna Anticlines. The structural thickness of the lower Torok in the foothills belt is in excess of $8,200 \mathrm{ft}$ in the Awuna well within NPRA, and in excess of 8,500 $\mathrm{ft}$ in the Tulugak 1 well southeast of NPRA. The extreme structural disruption of the lower Torok in structural domain 2 precludes determination of its original stratigraphic thickness there, but in the Seabee 1 well in domain 1, where this unit is only mildly deformed, the stratigraphic thickness of the lower Torok is about 5,400 ft. South of the Seabee 1 well, toward the axis of the Colville Basin, the original stratigraphic thickness of the lower Torok was likely much greater.

Anticlinal folding of lower Torok sandstones occurred mainly in structural domain 2 (the major passive-roof duplex; fig. TS3). The complex thrust-imbrication of these rocks produced arrays of folds that in places affected thousands of feet of lower Torok sandstones (figs. TS5, TS10). In domain 1, the lower Torok sandstones are relatively undeformed and are detached from overlying highly deformed Torok mudstones. Hypothetical structurally trapped hydrocarbon accumulations in domain 1 would be present only in poorly imaged sandstone bodies intercalated with chaotically deformed upper Torok mudstones in the cores of Umiat-style anticlines, or within the structurally thickened Torok welt to the north.

In an eastward extension of this play in the foothills south of NPRA, a natural gas accumulation was discovered in lower Torok sandstones in the East Kurupa 1 well, in a structural closure on the east end of the Kurupa Anticline (fig. TS2, TS11). Drill-stem tests indicate the presence of three gas-bearing sandstone bodies in the lower Torok at depths between 7,000 ft and 9,500 ft (Kumar and others, 2002). The tests indicate moderate overpressures of 0.53 to $0.56 \mathrm{psi} / \mathrm{ft}$ (P.H. Nelson, U.S. Geological Survey, 
written communication, 2002). The area of closure on the top of the lower Torok is about 7,500 acres (Kumar and others, 2002), although this might not correspond to the area of the gas pool, which could be limited by discontinuous reservoir horizons or fault compartmentalization within the anticline.

This play is primarily a gas play, evidenced by the nearly ubiquitous gas shows in exploration wells penetrating the lower Torok. Possible Brookian source rocks are deltaic strata and thus would most likely be gas prone. Although this play has the potential to be charged by hydrocarbons expelled from the GRZ, Kingak Shale, and Shublik Formation source rock intervals that are more oil-prone than the Torok (Houseknecht, Chapter BK, this volume), it lies at levels of thermal maturity that are mainly within the gas window.

\section{PLAY ATTRIBUTES}

\section{Volumetric Parameters}

Reservoir thickness The reservoirs within structural traps in this play consist of stacked folded sandstone bodies, each of which would ideally be isolated from those above and below it by intervening shale drapes. The net reservoir thickness represents the total thickness of producing sandstone reservoirs that might be penetrated in a hypothetical oil or gas field. Net thickness values are partly constrained by sand-shale ratios observed and interpreted in wells that penetrate significant thicknesses of the lower Torok, such as the East and West Kurupa wells, the Seabee 1 well, and the Awuna 1 well. Overall thicknesses of the folded lower Torok, interpreted from regional seismic lines, range from 2,000 to 7,200 ft (thinner intervals of more mud-rich Torok are also included in this play). The sand-shale ratios in lower Torok interpreted from the wells referenced above are about 20 percent. It is important to recognize that only a few of these sandstone bodies will have reservoir-quality porosities. The resulting distribution of net reservoir thicknesses for oil accumulations includes a lower truncation value of $40 \mathrm{ft}$, a median value of $100 \mathrm{ft}$, and a maximum of $500 \mathrm{ft}$ (table TS5). For gas accumulations, the lower truncation value is $50 \mathrm{ft}$, the median value is $200 \mathrm{ft}$, and the maximum is $1,000 \mathrm{ft}$ (table TS5). The greater reservoir thicknesses for gas reflect the lower porosities allowable for gas reservoirs. Drill-stem tests in East Kurupa 1 (Kumar and others, 2002) indicate that tested intervals of lower Torok sandstones totaling about $320 \mathrm{ft}$ produced substantial gas flows, so this thickness may be taken as an upper bound on the producing reservoir thickness in that well. This observation is consistent with, and helped guide, the specified distribution of net reservoir thicknesses. 
Area of closure As in the Brookian Topset Structural Play, our analysis of deformed Torok strata on regional seismic lines, as well as Saltus and others' (Chapter SM, this volume) statistical analysis of four-way closures from the Tetra Tech (1980, 1982) interpretations, were used to constrain the areas of closure for prospects in this play. In our analyses of regional seismic reflection data for this play, we measured widths of anticlines that affect the lower Torok on north-south dip lines and applied aspect ratios of 5.5:1 (for standard anticlines) and 2:1 (for frontal welts), to calculate the areas of hypothetical elliptical closures. This approach yielded areas of closure similar to those calculated by Saltus and others for anticlines in the lower Torok. The seismic reflection data show that, within large anticlines defined by the top of the lower Torok (with areas of tens to hundreds of thousands of acres), there are typically numerous smaller anticlinal closures (thousands of acres) that would form the actual structural traps. In addition, there is a strong likelihood that reservoirs within these smaller anticlines would be compartmentalized by thrust faults. For example, the very prominent lower Torok reflector on the left (south) part of figure TS5 has been folded and thrustfaulted, and reflections within the individual anticlines are disrupted, indicating additional faulting within the structures. Some of these faults would be characterized by smeared shale, providing fault seals that would compartmentalize a reservoir.

Kumar and others (2002) estimated the area of closure on the East Kurupa gas accumulation to be 7,500 acres, based on examination of the local structural closure. Our examination of regional seismic lines yield similar values for typical anticlines affecting the lower Torok near the East Kurupa well (although the overall area represented by the Kurupa anticline, which envelopes these smaller structures, might be as large as 100,000 acres).

Based largely on the concept of reservoir compartmentalization by faulting within anticlines, we adopted a median area of 5,000 acres for this play, with F05 and maximum areas of 30,000 (F05) and 40,000 (MAX) acres for oil; and 50,000 (F05) and 100,000 (MAX) acres for gas (table TS5). The F05 and maximum values for oil allow for a few large unbroken oil reservoirs in large, structurally simple anticlines. The larger areas for gas reservoirs, at the high end, reflect the possibility of a widespread, lower-porosity gas reservoir draped over a large anticlinal structure and enhanced by fracturing, whereas oil accumulations require higher-porosity reservoirs that might be limited to facies-bounded compartments.

We applied a +0.3 correlation between area of closure and net reservoir thickness for the Torok Structural Play (Scheunemeyer, Chapter ME, this volume). Although 
Saltus and others (Chapter SM, this volume) determined a very strong positive correlation between the area and height of closures defined by the Tetra Tech (1982) Horizon FM, this does not translate into a strong positive correlation between area of closure and net reservoir thickness for this play. This is because the amplitude of an anticlinal closure has little relation to the reservoir thickness in this play, where reservoirs are confined to a single or few horizon(s) with favorable physical characteristics and adequate seals. The +0.3 correlation is invoked in order to allow for those less common situations in which there is a large proportion of adequate reservoir strata within topset strata, in which case larger structures would imply thicker reservoirs.

Porosity and hydrocarbon pore volume. The oil-prospective part of the Torok Structural Play overlaps the Brookian Clinoform South-Shallow Stratigraphic Play (Houseknecht, Chapter BK, this volume) and the porosity values shown in table TS5 for oil in the Torok Structural Play are identical to those in the Brookian Clinoform SouthShallow Stratigraphic Play. Likewise, the gas-prospective deeper part of the Torok Structural Play overlaps the Brookian Clinoform South-Deep Stratigraphic Play, and the porosity values shown in table TS5 for gas in the Torok Structural Play are identical to those in the Brookian Clinoform South-Deep Stratigraphic Play. These values, in general, correspond to the high end of porosity values determined for Torok sandstones from core measurements, electric logs, and sonic logs from the Seabee 1, West Kurupa, East Kurupa, Awuna 1 and Big Bend wells. Typical lower Torok sandstones are probably not reservoir-quality (Houseknecht and Schenk, 2001), so our reservoir porosity values represent exceptional, rather than typical, reservoir conditions expected to exist in this unit. Intense fracturing is expected to locally enhance the porosity.

As with the Brookian Topset Structural Play, we applied a -0.5 correlation between porosity and net reservoir thickness for the Torok Structural Play (Scheunemeyer, Chapter ME, this volume).

The hydrocarbon pore volume is specified as the difference between the porosity(fl) and the porosity - water saturation product (flS w) (Scheunemeyer, Chapter $\mathrm{ME}$, this volume). Water saturation is based on analogs from similar lithic arenite reservoirs (Nelson, 1999). 
Table TS5. Probability distribution of volumetric and spatial parameters for oil and gas in Torok Structural Play. LTP, left truncation point defining the lowest values for each parameter considered in the statistical distribution (Scheunemeyer, Chapter ME, this volume).

Attribute

Net Reservoir Thickness (oil)

Net Reservoir Thickness (gas)

Area of Closure (oil)

Area of Closure (gas)

Trap Fill (oil)

Trap Fill (gas)

Porosity (oil)

Porosity (gas)

Porosity - Water Saturation Product (oil)

Porosity - Water Saturation Product (gas)

Hydrocarbon Pore Volume (oil)

Hydrocarbon Pore Volume (gas) $\underline{\text { Units }}$

feet

feet

1000 acres

1000 acres

percent

percent

percent

percent

percent

percent

percent

percent

$1000 \mathrm{ft}$

$1000 \mathrm{ft}$

Trap Depth (gas)

Number of Prospects

Trap Depth (oil)
Probability of attribute greater than

$\underline{\text { LTP }} \quad \underline{50} \quad \underline{5} \quad \underline{M a x}$

$\begin{array}{llll}40 & 100 & 250 & 300\end{array}$

$\begin{array}{llll}50 & 200 & 500 \quad 1000\end{array}$

$\begin{array}{llll}2 & 5 & 30 & 40\end{array}$

$\begin{array}{llll}2 & 5 & 50 & 100\end{array}$

$\begin{array}{llll}20 & 40 \quad 80 & 100\end{array}$

$\begin{array}{llll}40 & 75 & 85 & 100\end{array}$

$\begin{array}{llll}10 & 12 & 16 & 20\end{array}$

$\begin{array}{llll}8 & 11 & 14 & 17\end{array}$

5

5

$\begin{array}{llll}5 & 7 & 11 & 15\end{array}$

$\begin{array}{llll}3 & 6 & 9 & 12\end{array}$

$\begin{array}{lll}\text { Min } & 50 & 5\end{array}$

$\begin{array}{rrrr}3 & 5 & 9 & 10 \\ 1 & 4 & 15 & 20 \\ 60 & 90 & 120 & 150\end{array}$


Trap Fill The same trap fill distribution is used for this play as for the Brookian Topset Structural Play (tables TS1, TS5). Even though migration pathways from source to trap are somewhat shorter in this play, trap fill in these structural plays is likely to be strongly affected by fractured and faulted leaky seals.

Trap depth We have specified separate distributions for the depths to the top of oil and gas accumulations in the Torok Structural Play. Thermal maturity patterns strongly suggest that oil prospects would be distributed mainly (but perhaps not exclusively) in the northern two-thirds of the play area, where the top of the lower Torok reservoir facies lies at depths over 3,000 ft, and the base of the oil window undulates (as discussed above in Overview of the Brookian Plays), but nowhere includes lower Torok rocks deeper than 11,000-13,000 ft. Thus, for depths to the tops of structural traps for oil accumulations, we assign a range of 3,000-10,000 ft, with a median of 5,000 ft (table TS5). Because folded reservoir rocks are present at shallower depths in the gas-prone, southernmost part of the play area, and are also present at great depth within the Torokdominated passive-roof duplex, the depth range for structural traps for gas accumulations is $1,000-20,000 \mathrm{ft}$, with a median of 4,000 ft (table TS5).

Number of Prospects The closure analysis for Tetra Tech Horizon FM (Saltus and others, Chapter SM, this volume) identified 77 structural closures that exceed the minimum area. However, several of these are erosionally breached. Therefore, we have established a minimum number of 60 drillable prospects (table TS5). The median and maximum values of 90 and 150 (table TS5) reflect the concept that reservoirs within many of the large anticlines are likely to be compartmentalized, either stratigraphically or structurally, so that there might be more than one prospect in a given anticline.

\section{Oil and Gas parameters}

Oil recovery factor The oil recovery factor of 30 percent (table TS5) reflects the fact that this play might be significantly affected by faults to a greater degree than the Brookian Topset Structural Play. Verma (Chapter OG, this volume) discusses the range of recovery factors used in the oil and gas assessment of NPRA.

Table TS6. Oil and gas parameters for Torok Structural Play.

$\begin{array}{llc}\text { Parameter } & \text { Units } & \text { Value } \\ \text { Oil recovery factor } & \text { percent } & 30 \\ \text { Non-associated gas recovery factor } & \text { percent } & 60\end{array}$




$\begin{array}{llr}\text { Oil gravity } & \text { API degrees } & 28 \\ \text { Sulfur content of oil } & \text { wt. percent } & 1.2 \\ \text { Gas-oil ratio at median depth } & \text { cubic ft / bbl } & 438\end{array}$

Non-associated gas recovery factor The non-associated Gas Recovery Factor is set at 60 for this play, reflecting the faulted nature of the play.

Oil gravity and sulfur content The oil in this play is considered to have components of Torok Formation, GRZ, and Kingak Shale sources, so we have assigned values reflecting a mix of these oil types. Oil gravity is set at 28 API, and sulfur content is set at 1.2 percent for this play (table TS6).

GOR at median depth Determination of the gas-oil ratio is discussed by Verma (Chapter OG, this volume).

\section{Probability of occurrence}

Play This is not a proven play. Although its eastern extension includes at least one gas accumulation very near NPRA (East Kurupa), this accumulation has not been proven to be of minimum size. The presence of this accumulation allows us to set playlevel risking attributes for Charge $(\mathrm{C})$ and Timing $(\mathrm{T})$ at 1 , whereas the uncertainty with respect to the size of the reservoir has resulted in a value of 0.9 for the Trap/Seal (T) attribute (table TS7). Thus, the overall play risk (probability that the play contains at least 1 reservoir of at least the minimum size) is 0.9 (table TS7).

Prospect At the prospect level, we have established separate risking parameters for oil and gas, as with the Brookian Topset Structural Play.

Charge: We assigned probability values of 0.2 for oil charge, and 0.9 for gas charge in the Torok Structural Play (table TS7), for essentially the same reasons as in the Brookian Topset Structural Play. There is significant evidence for overpressures in the lower Torok in several wells in this play, based on mud-weight and sonic logs, and drillstem tests (P.H. Nelson, U.S. Geological Survey, written commun., 2001); this is considered further evidence for widespread gas charge.

Trap: Trap risk is high for both oil and gas, because this play relies upon turbidite sandstones as reservoirs, and seals might be ineffective because of faulting and 
fracturing. We set the prospect-level trap (t) probability at 0.2 for both oil and for gas (table TS7).

Timing: We assigned probability values of 0.7 for oil timing, and 0.9 for gas timing in the Torok Structural Play (table TS7), for essentially the same reasons as in the Brookian Topset Structural Play. 
Table TS7. Probability of occurrence for play and prospects, Torok Structural Play

$\begin{array}{lrr}\text { Play Attributes } & \text { OIL } & \text { GAS } \\ \text { Charge }(C) & 1 & 1 \\ \text { Trap }(T) & 0.9 & 0.9 \\ \text { Timing (F) } & 1 & 1 \\ \text { Probability that play contains at least 1 reservoir exceeding } & 0.9 & 0.9 \\ \text { minimum size (CxTxF) } & & 0.9 \\ \text { Prospect Attributes } & 0.2 & 0.9 \\ \text { Charge (c) } & 0.2 & 0.2 \\ \text { Trap (t) } & 0.7 & 0.9 \\ \text { Timing (f) } & 0.03 & 0.16 \\ \text { Probability that a randomly chosen prospect is favorable (cxtxf) } & & \\ & & 0.15\end{array}$

Aggregate Risking Parameters For oil, the prospect-level risk is $[(\mathrm{CTF}) \times(\mathrm{ctf})]=[0.9 \times(0.2 \times 0.2 \times 0.7)]=0.03$. For gas, this risk is

$[(\mathrm{CTF}) \times(\mathrm{ctf})]=[0.9 \times(0.9 \times 0.2 \times 0.9)]=0.15$ (table TS7). Thus, 3 percent of prospects would be expected to contain a minimum-sized accumulation of oil, whereas 15 percent of prospects would be expected to contain a minimum-sized accumulation of gas.

Fraction of accumulations being oil This value is set at 0.10 for this play, based on the common presence of gas shows in wells, and the fact that no oil accumulations have been found in the Torok Structural Play in and near NPRA.

\section{RESULTS}


The assessment input values summarized in tables TS5, TS6, and TS7 were used to estimate the petroleum resource potential of the Torok Structural Play. Results are summarized in table TS8 for technically recoverable crude oil and non-associated gas. Additional results are provided in Appendix XX. 
Table TS8. Estimates of volumes of technically recoverable hydrocarbons in the Torok Structural Play in NPRA.

\begin{tabular}{|c|c|c|c|c|c|}
\hline & $\underline{\text { Mean }}$ & $\underline{\text { Std. Dev }}$ & $\underline{\mathrm{F}_{95}}$ & $\underline{\mathrm{F}}_{\underline{50}}$ & $\underline{\mathrm{F}}_{\underline{05}}$ \\
\hline Oil (MMBO) & 35 & 101 & 0 & 0 & 222 \\
\hline Non-associated Gas (BCF) & 17905 & 10120 & 0 & 17769 & 35012 \\
\hline
\end{tabular}

It is estimated that this play contains 35 million barrels of technically recoverable oil and 17.9 TCF of technically recoverable, non-associated natural gas, with both values representing the mean estimate (expected value).

The oil and gas resources are estimated to occur in accumulations of various size, as illustrated in figures TS12 and TS13. There is a very small probability of the existence of one or more oil accumulations of any size within the Torok Structural Play, as illustrated in figure TS12A. The volumes of oil within this play are expected to occur in accumulations between 128 and $512 \mathrm{MMBO}$ in size (fig. TS12B).

It is estimated that there is approximately one natural gas accumulation between 3,072 and 6,144 BCF in this play, along with about two each in the 192 to 384 and 1,536 to $3,072 \mathrm{BCF}$ size classes and about three each in the 768 to 1,536 and 384 to $768 \mathrm{BCF}$ size classes (fig. TS 13A). Individual accumulations larger than 6 TCF are unlikely (fig. TS 13a). Most of the gas in this play is expected to occur in accumulations between about 1.5 and 6 TCF in size (fig. TS13b).

In addition to volumes of crude oil and non-associated gas, this play also contains relatively small volumes of associated natural gas and natural gas liquids, and those values are reported in Appendix XX. 


\section{REFERENCES}

Brosg, W. P., and Whittington, C. L., 1966, Geology of the Umiat-Maybe Creek region, Alaska: U.S. Geological Survey Professional Paper 303-H, p. 501-638.

Burns, W.M., Hayba, D.O., Houseknecht, D.W., and Rowan E.L., 2002, Timing of hydrocarbon generation in the National Petroleum Reserve-Alaska (NPRA) from burial and thermal history modeling [abs.]: American Association of Petroleum Geologists Pacific Section Meeting, Anchorage, May, 2002.

Cole, F., Bird, K. J., Toro, J., Roure, F., O'Sullivan, P. B., Pawlewicz, M., and Howell, D. G., 1997, An integrated model for the tectonic development of the frontal Brooks Range and Colville Basin $250 \mathrm{~km}$ west of the Trans-Alaska Crustal Transect: Journal of Geophysical Research, v. 102, p. 20,685-20,708.

Deming, D., Sass, J.H., Lachenbruch, A.H., and DeRito, R.F., 1992, Heat flow and subsurface temperature as evidence for basin-scale groundwater flow, North Slope of Alaska: Geological Society of America Bulletin, v. 104, p. 528-542.

Houseknecht, D.W., and Schenk, C.J., 2001, Depositional sequences and facies in the Torok Formation, National Petroleum Reserve - Alaska (NPRA), in Houseknecht, D.W. (editor), NPRA Core Workshop - Petroleum Plays and Systems in the National Petroleum Reserve - Alaska: Society of Economic Paleontologists and Mineralogists Core Workshop No. 21, p. 179-199.

Kumar, N., Bird, K.J., Nelson, P.H., Grow, J.A., and Evans, K. R., 2002, A digital atlas of hydrocarbon accumulations within and adjacent to the National Petroleum Reserve-Alaska (NPRA), U.S. Geological Survey Open-File Report 02-71, 80 p.

Mayfield, C.F., Tailleur, I.L., and Ellersieck, Inyo, 1988, Bedrock geologic map of the National Petroleum Reserve in Alaska, Chapter 8, in Gryc, George, ed., Geology and Exploration of the National Petroleum Reserve in Alaska, 1974 to 1982: U.S. Geological Survey Professional Paper 1399, p. 187-190, 2 plates.

Miller, J.J., Agena, W.F., Lee, M.W., Zihlman, F.N., Grow, J.A., Taylor, D.J., Killgore, M., Oliver, H.L., 2000, Regional seismic lines reprocessed using post-stack processing techniques: National Petroleum Reserve - Alaska (NPRA), U. S. Geological Survey Open-File Report 00-286. 
Miller, J.J, Agena, W. F., Lee, M.W., Zihlman, F.N., Grow, J.A., Taylor, D.J., Killgore, Michele, and Oliver, H.L, 2001, Four Regional Seismic Lines: National Petroleum Reserve -- Alaska (Supplement to U.S. Geological Survey Open-File Report 00-286), U.S. Geological Survey Open-File Report 01-0337. (http://geology.cr.usgs.gov/pub/open-file-reports/ofr-01-0337/)

Molenaar, C.M., 1982, Umiat field, an oil accumulation in a thrust-faulted anticline, North Slope of Alaska, in Powers, R.B., ed., Geologic studies of the Cordilleran Thrust Belt: Rocky Mountain Association of Geologists, Denver, p. 537-548.

Nelson, P.H., 1999, Petrophysical properties-Chapter PP, in ANWR Assessment Team, The Oil and Gas Resource Potential of the 1002 Area, Arctic National Wildlife Refuge, Alaska: U.S. Geological Survey Open-File Report 98-34 (CD-ROM), p. PP-1-PP-64.

O’Sullivan, P.B., Murphy, J.M., and Blythe, A.E., 1997, Late Mesozoic and Cenozoic thermotectonic evolution of the central Brooks Range and adjacent North Slope foreland basin, Alaska-including fission track results from the Trans-Alaska Crustal Transect (TACT): Journal of Geophysical Research, v. 102, p. 20,82120,845 .

Perry, W.J., Potter, C.J., and Nelson, P.H., 1999, Thin-skinned thrust-belt play-Chapter P8, in ANWR Assessment Team, The Oil and Gas Resource Potential of the 1002 Area, Arctic National Wildlife Refuge, Alaska: U.S. Geological Survey Open-File Report 98-34 (CD-ROM), p. P-34-P-40.

Reed, J.C., 1958, Exploration of Naval Petroleum Reserve No. 4 and adjacent areas-Northern Alaska, 1944-53-Part 1, History of the exploration: U.S. Geological Survey Professional Paper 301, 192 p., 3 plates.

Tetra Tech, 1980, Summary geophysical report, FY80: Tetra Tech Report No. 8003 (including maps at 1:250,000 scale).

Tetra Tech, 1982, Petroleum exploration of NPRA 1974-1981 (final report): Tetra Tech Report No. 8200 (including maps at 1:500,000 scale). 


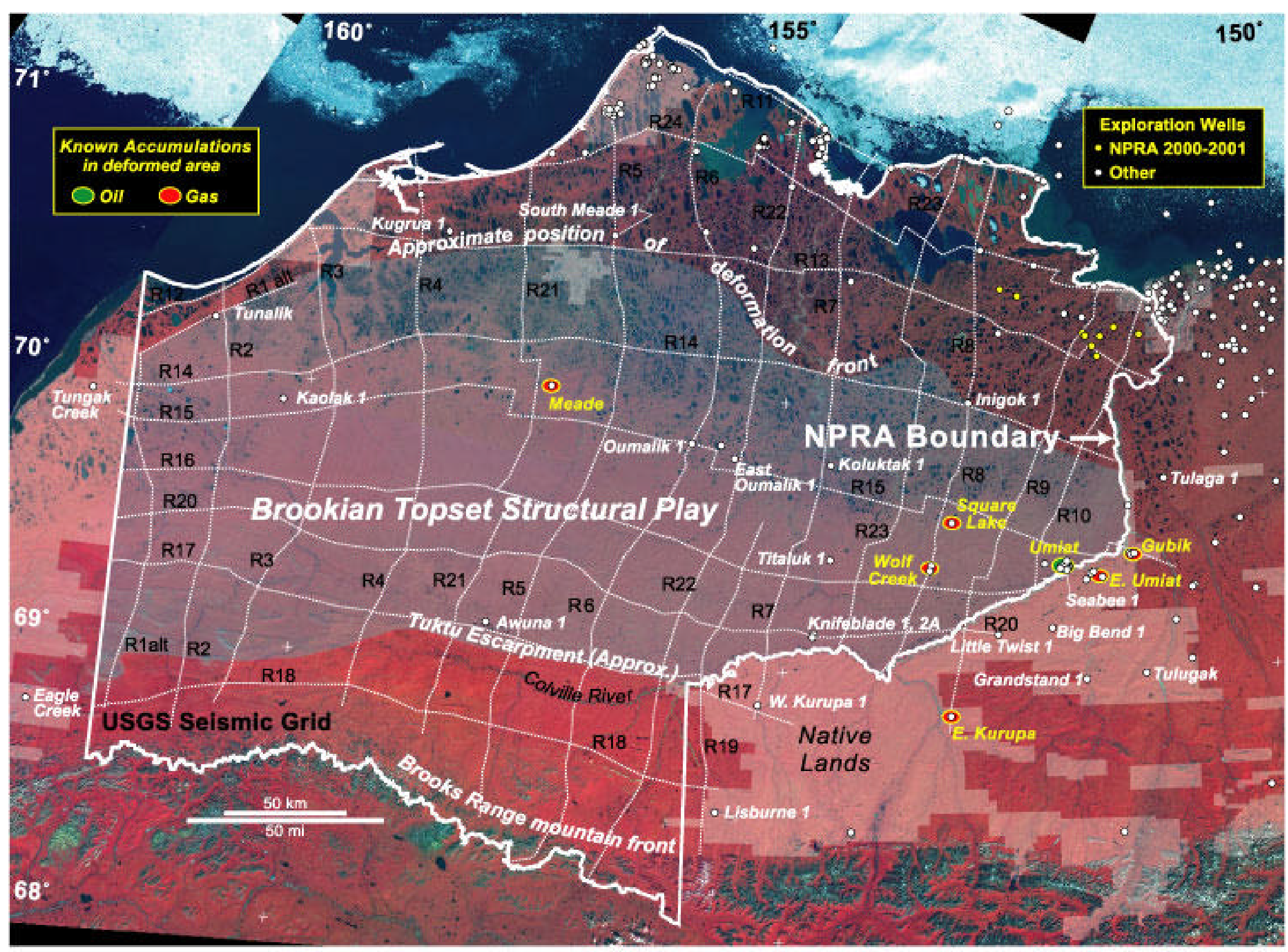

Figure TS1. Brookian Topset Structural Play superimposed on LANDSAT false-color satellite image. 


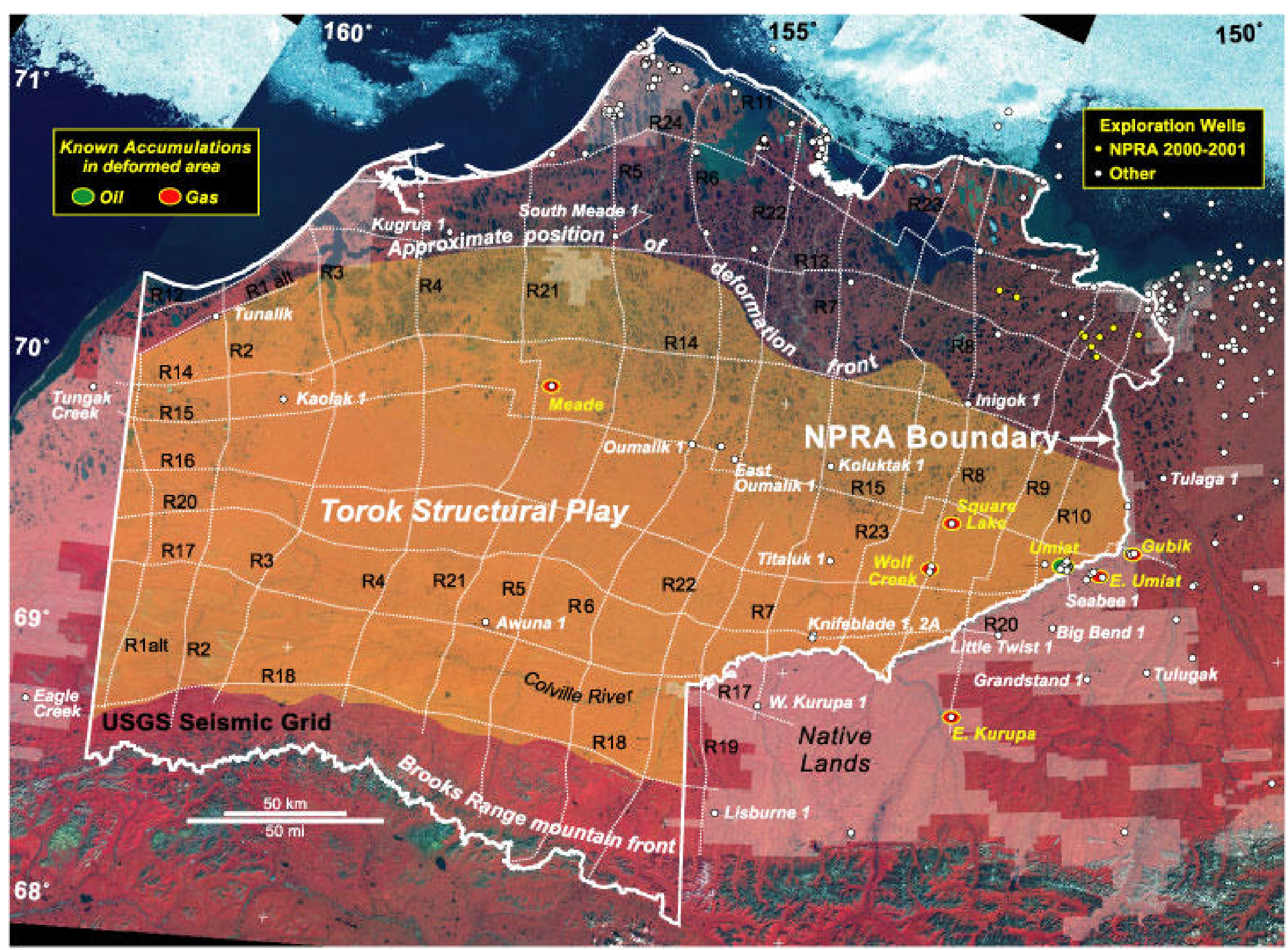

Figure TS2. Torok Structural Play superimposed on LANDSAT false-color satellite image. 


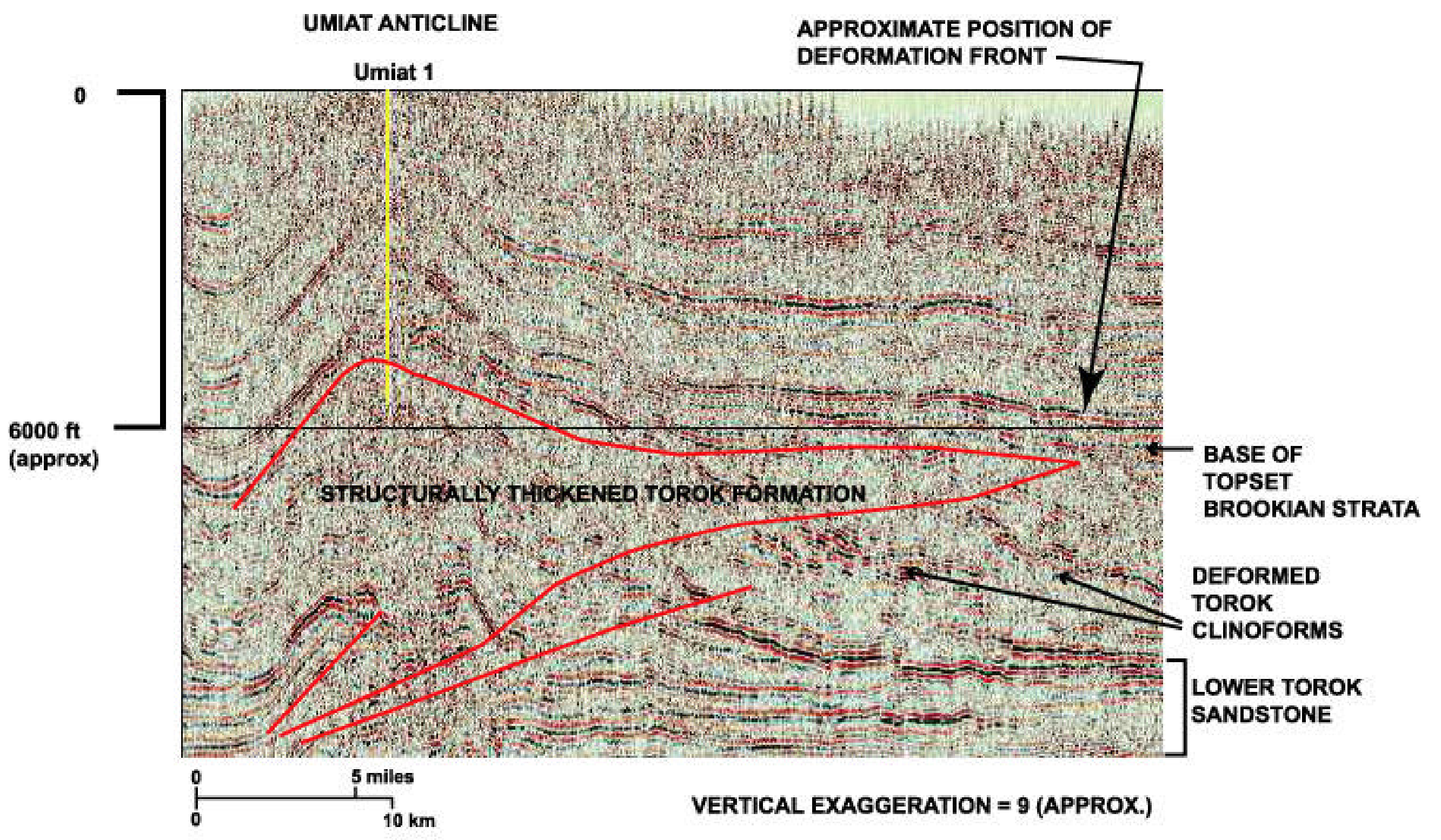

Figure TS4. Seismic reflection data from NPRA Regional line R-10 illustrating Umiat Anticline and broad, low-amplitude anticline to its north. 


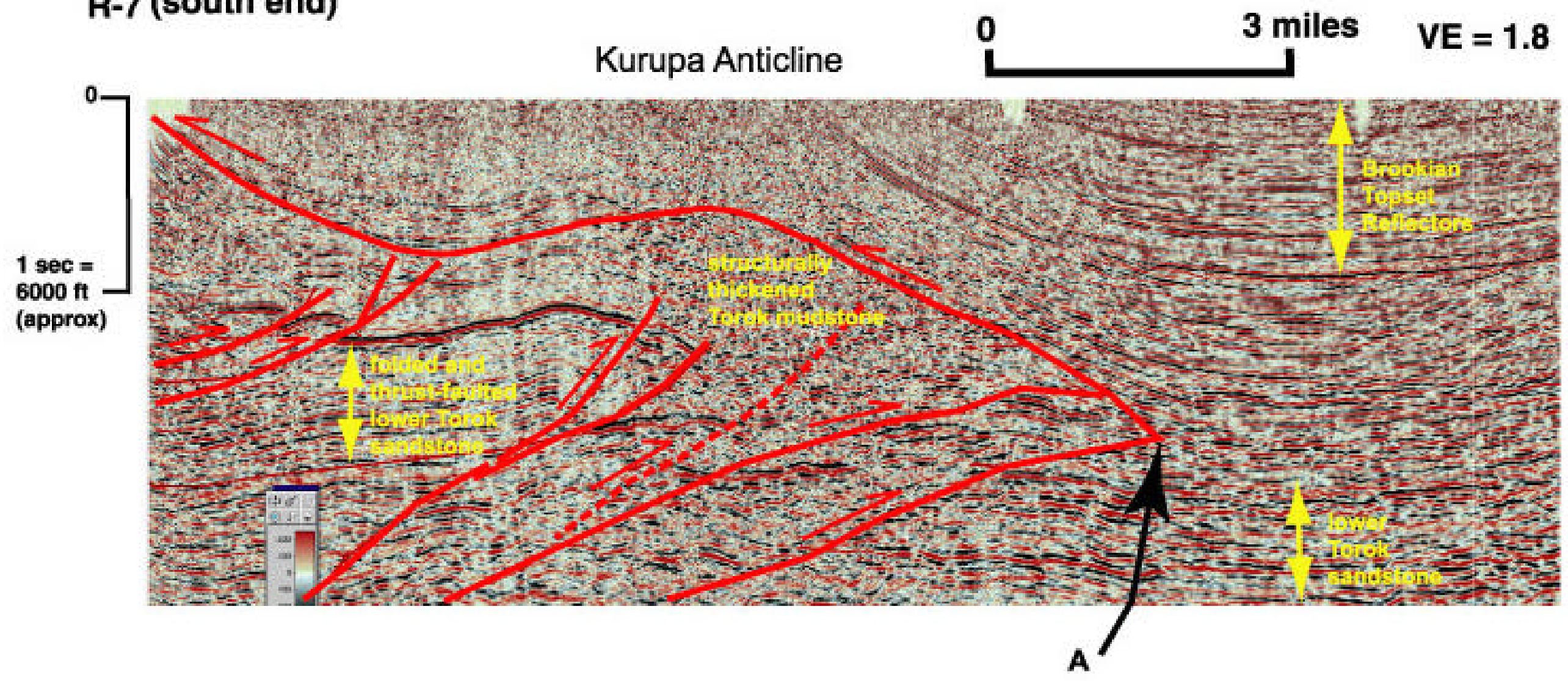

Figure TS5. Seismic reflection data from south end of NPRA Regional line R-7, near West Kurupa 1, illustrating interpretation of the tip of a passive roof duplex, within which thrust-faulted anticlines are developed in lower Torok Formation sandstones beneath the composite Kurupa anticline and adjacent syncline. The point labeled $\mathbf{A}$ is interpreted as the apex of Torok tectonic wedge (passive roof duplex), and corresponds to point labeled $\mathbf{A}$ in the generalized cross section shown in figure TS3. 


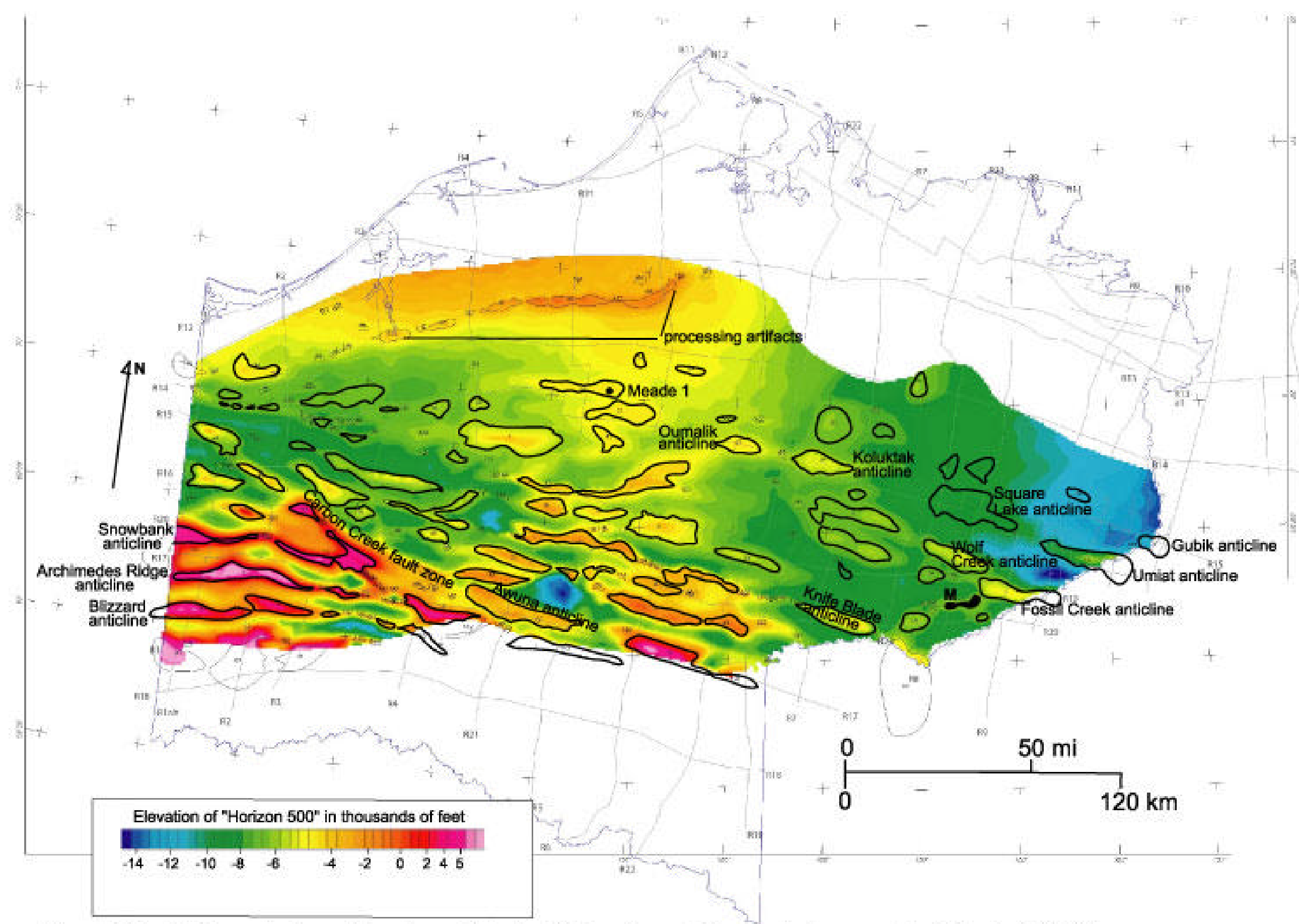

Figure TS6. Saltus and others (this volume, Chapter SM) analyses of structural closures using Tetra Tech (1982)

Horizon 500, with key anticlines labeled. Horizon 500 is within the Brookian topset seismic facies. Scale is nonlinear. Elevations above ground elevation represent projection of eroded horizon above ground surface. Processing artifacts are related to correction of datum shifts (Saltus and others, this volume, Chapter SM), and do not reflect geologic structure. Closure labeled $\mathrm{M}$ corresponds to the median area of closure specified for this play. 


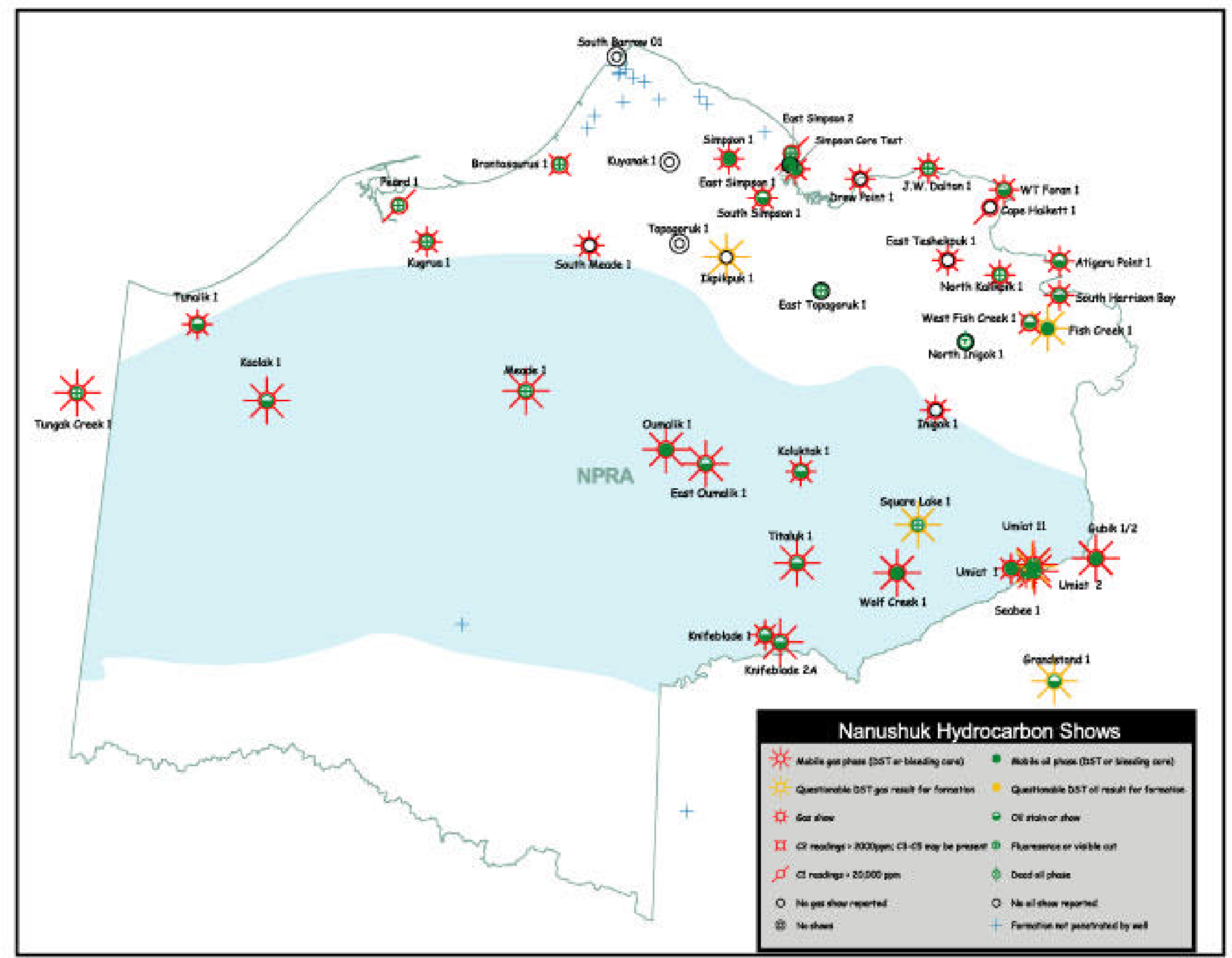

Figure TS7. Hydrocarbon shows in Nanushuk Group, in exploration wells in and near NPRA. Brookian Topset Structural Play area is shaded blue. 
A.

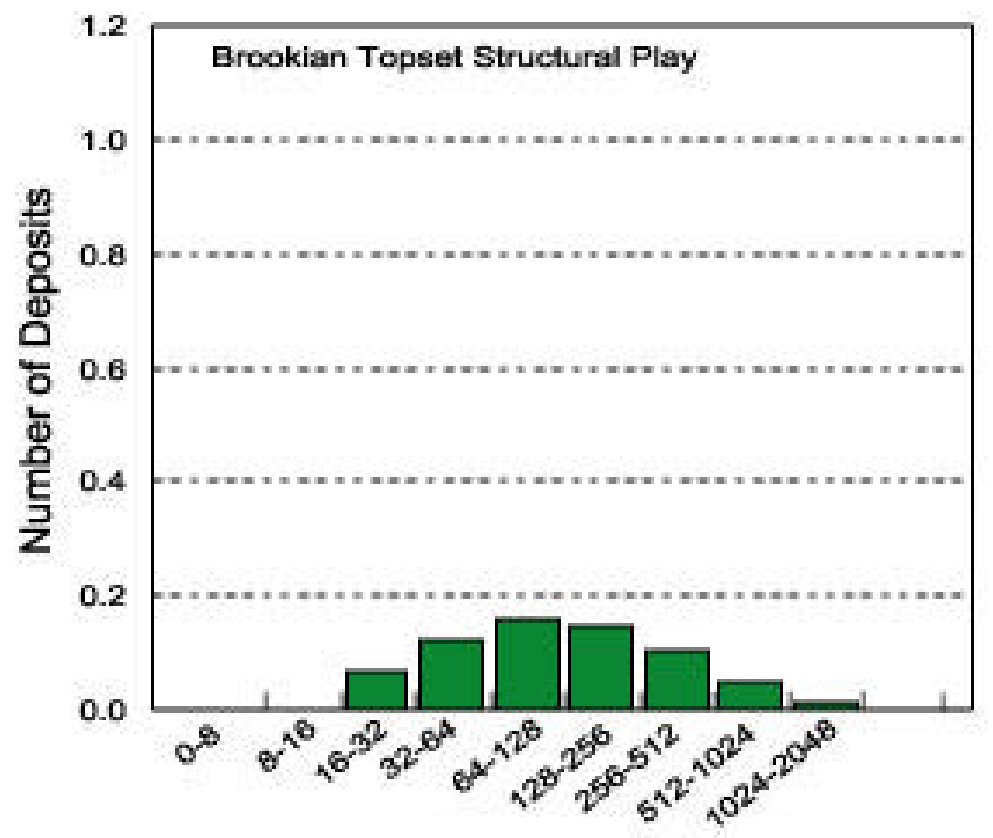

Size Ranges (MMBO)
B.

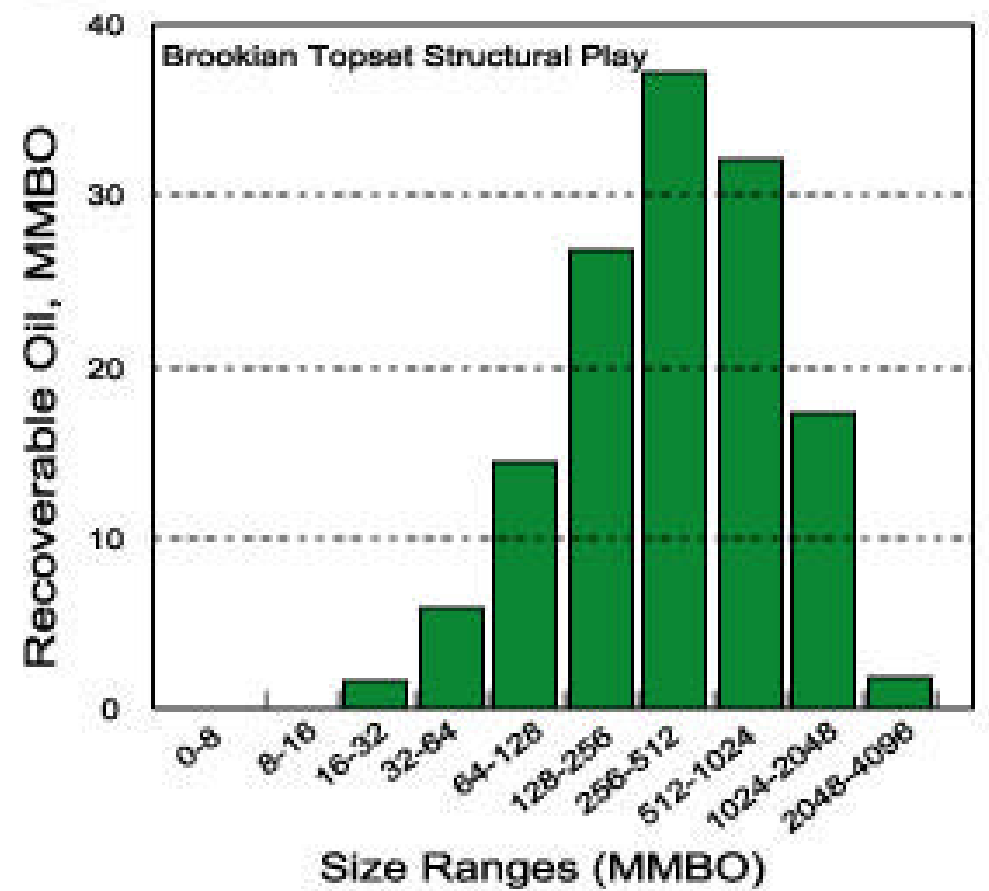

FigureTS8. Summary of oil accumulation sizes estimated for Brookian Topset Structural Play based on mean estimates of technically recoverable resources. A.) Estimated number of oil accumulations by size class. B.) Estimated volume of oil in accumulations of various size class. 
A.

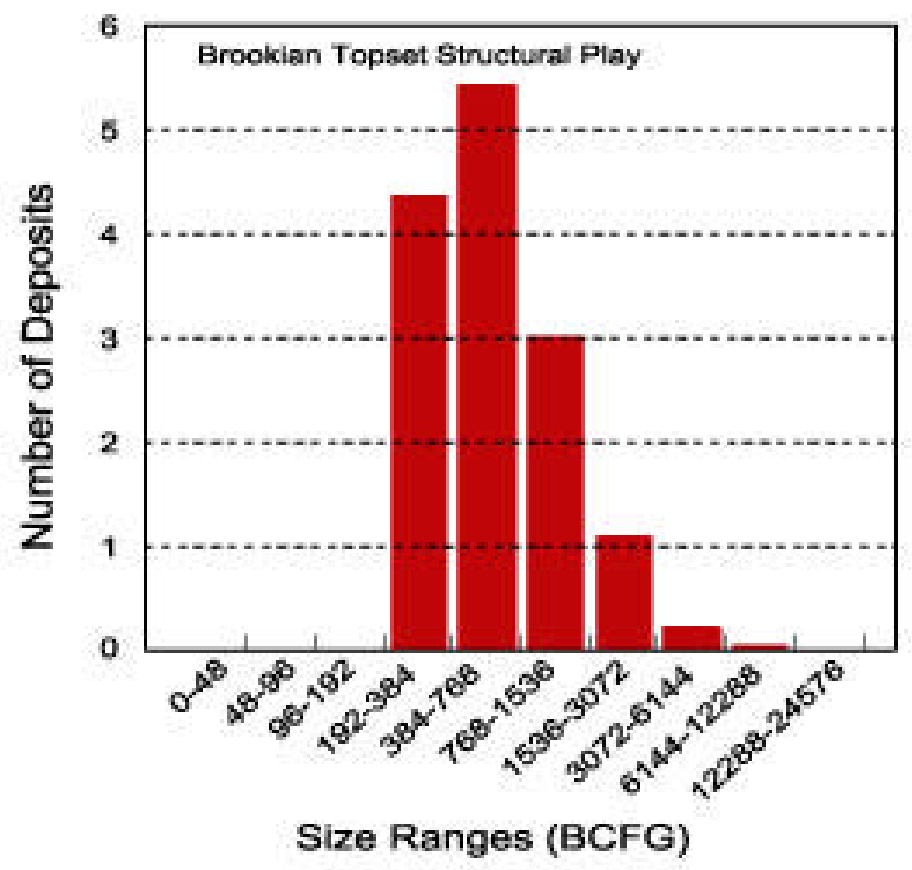

B.

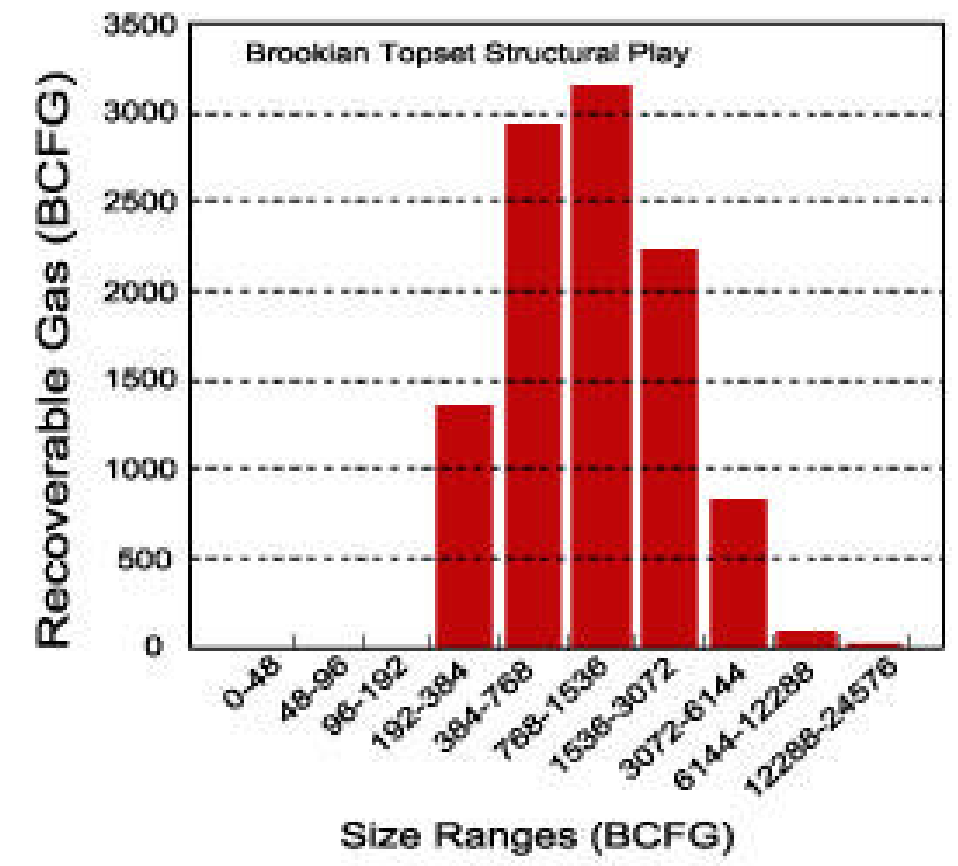

FigureTS9. Summary of natural gas accumulation sizes estimated for Brookian Topset Structural Play based on mean estimates of technically recoverable resources. A.) Estimated number of gas accumulations by size class. B.) Estimated volume of gas in accumulations of various size classes. 
South

R-19 $\quad]^{3 \text { miles }} V E=1.5$
North

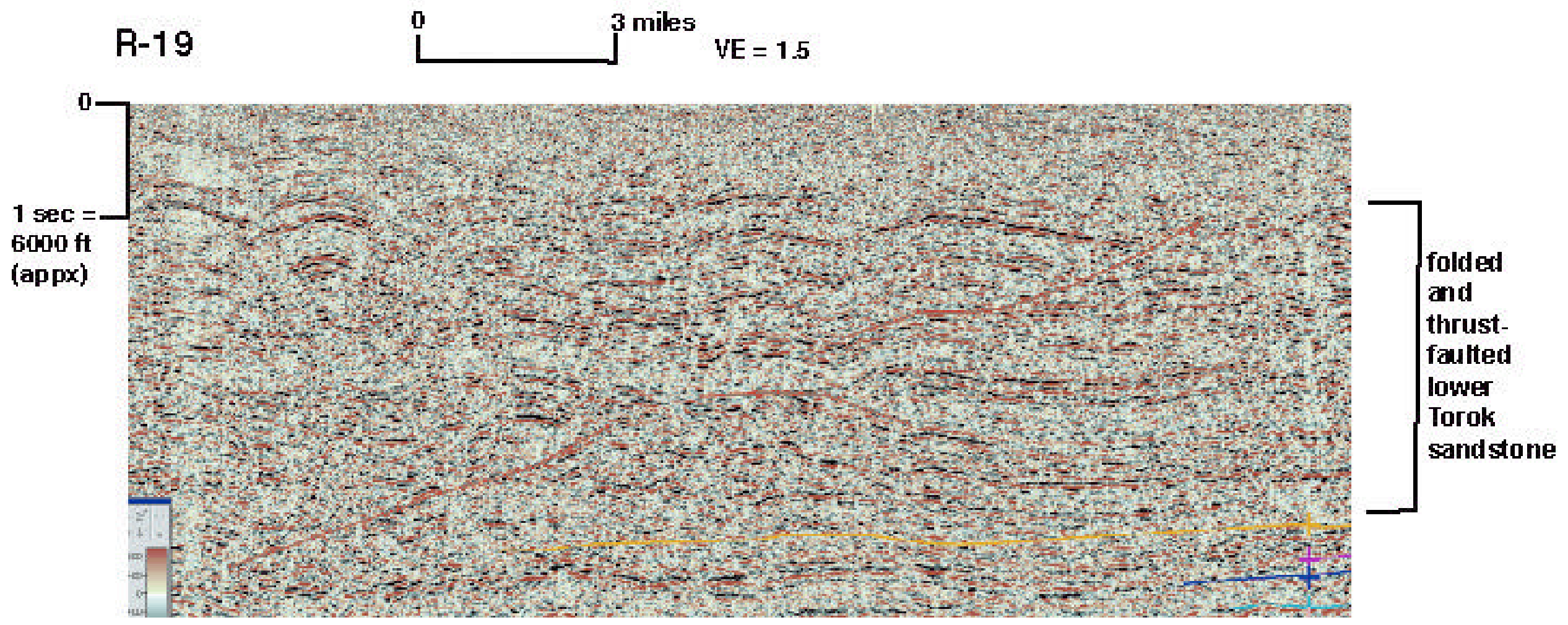

Figure TS10. Seismic reflection data from NPRA Regional line R-19 showing folds in lower Torok Formation. 


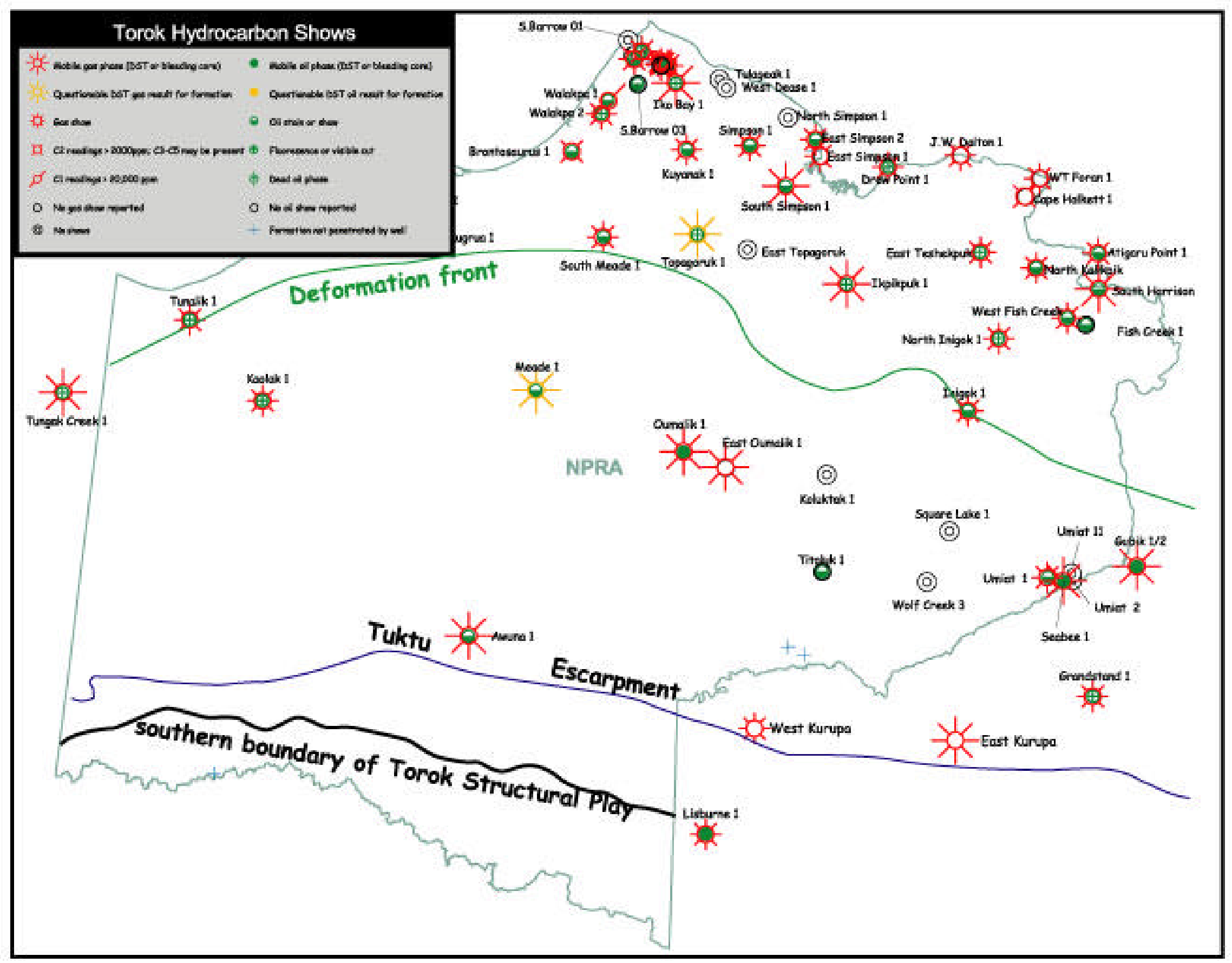

Figure TS11. Hydrocarbon shows in Torok Formation, in exploration wells in and near NPRA. Northern boundary of Torok Structural Play corresponds to deformation front. 

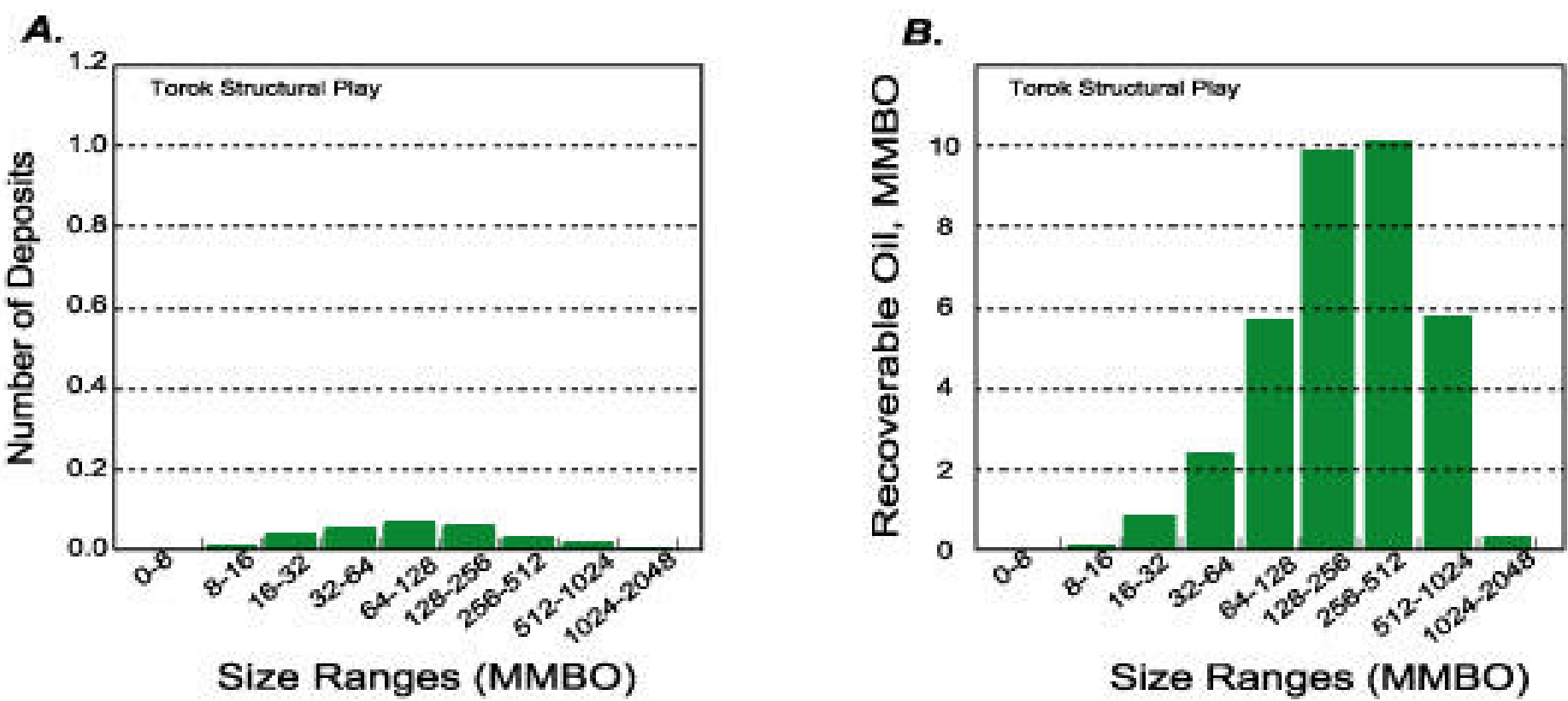

FigureTS12. Summary of oil accumulation sizes estimated for Torok Structural Play based on mean estimates of technically recoverable resources. A.) Estimated number of oil accumulations by size class. B.) Estimated volume of oil in accumulations of various size class. 
A.

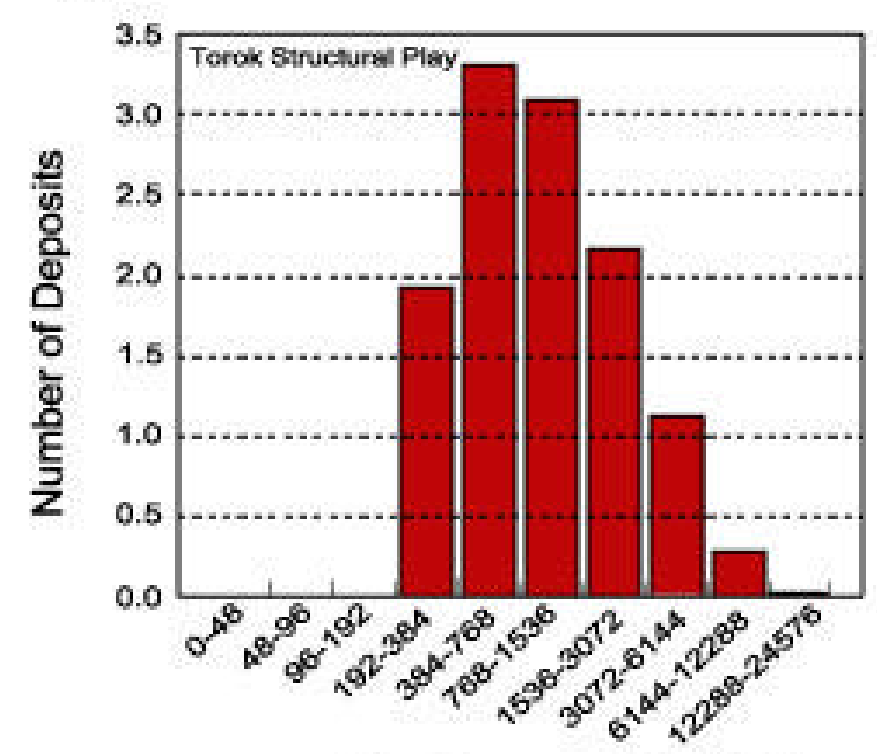

Size Ranges (BCFG)
B.

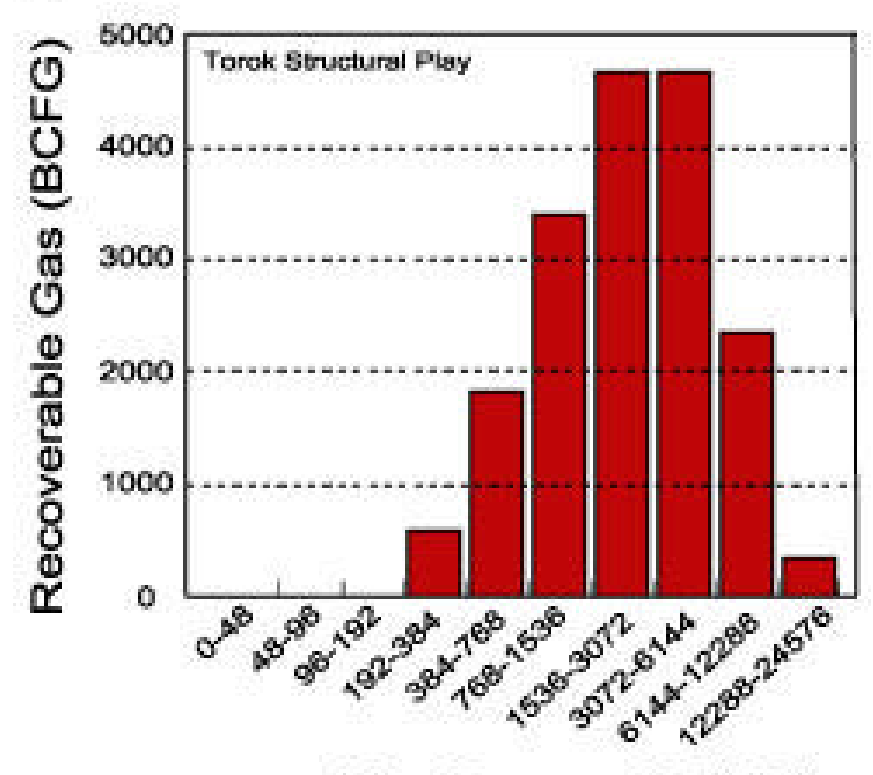

Size Ranges (BCFG)

FigureTS13. Summary of natural gas accumulation sizes estimated for the Torok Structural Play based on mean estimates of technically recoverable resources. A.) Estimated number of gas accumulations by size class. B.) Estimated volume of gas in accumulations of various size class. 